NBER WORKING PAPER SERIES

\title{
PUBLIC HOUSING, HOUSING VOUCHERS \\ AND STUDENT ACHIEVEMENT: \\ EVIDENCE FROM PUBLIC HOUSING DEMOLITIONS IN CHICAGO
}

\author{
Brian A. Jacob \\ Working Paper 9652 \\ http://www.nber.org/papers/w9652 \\ NATIONAL BUREAU OF ECONOMIC RESEARCH \\ 1050 Massachusetts Avenue \\ Cambridge, MA 02138 \\ April 2003
}

I would like to thank the Consortium on Chicago School Research, the Chicago Public Schools and the Chicago Housing Authority for providing the data used in this study and Ed Yong and Lee Burr for assistance interpreting data from the Housing Authority. I gratefully acknowledge the many helpful suggestions of Julie Cullen, Thomas DeLeire, Mark Duggan, Sue Dynarski, Carolyn Hill, Robin Jacob, Larry Katz, Jeff Kling, Robert LaLonde, Steven Levitt, Jens Ludwig, Susan Mayer, Sudhir Venkatesh, and Aaron Yelowitz. All remaining errors are my own. The views expressed herein are those of the authors and not necessarily those of the National Bureau of Economic Research.

C2003 by Brian A. Jacob. All rights reserved. Short sections of text not to exceed two paragraphs, may be quoted without explicit permission provided that full credit including Cnotice, is given to the source. 
Public Housing, Housing Vouchers and Student Achievement:

Evidence from Public Housing Demolitions in Chicago

Brian A. Jacob

NBER Working Paper No. 9652

April 2003

JEL No. J0, H0, H5, I0, I2

\section{$\underline{\text { ABSTRACT }}$}

There has been a substantial shift from public housing to voucher-based housing assistance over the past decade, largely in response to the rising cost of public housing and the high rates of crime, unemployment and school failure among public housing residents. Despite this shift, there is relatively little evidence on the impact of public housing or housing vouchers on educational outcomes. This paper utilizes a plausibly exogenous source of variation in housing assistance generated by public housing demolitions in Chicago to examine the impact of high-rise public housing on student outcomes. I find that children in households affected by the demolitions do no better or worse than their peers on a wide variety of achievement measures. Because the majority of households that leave public housing in response to the demolitions move to neighborhoods and schools that closely resemble those they left, the zero effect of the demolitions may be interpreted as the independent impact of public housing. These findings suggest that eliminating high-rise public housing will not necessarily lead to the benefits documented in housing mobility experiments such as Gautreaux or Moving to Opportunity

Brian A. Jacob

John F. Kennedy School of Government

79 JFK Street

Cambridge, MA 02138

and NBER

brian_jacob@harvard.edu 


\section{Introduction}

Over the past half-century, the federal government has taken on a considerable role in providing housing assistance to low-income individuals. The real costs of housing assistance have increased substantially over the past two decades, from $\$ 7.5$ billion in 1977 to over $\$ 26$ billion in 1997 . Outlays per unit nearly doubled over this period, from $\$ 2,980$ to $\$ 5,490$. The number of households assisted has also risen during this period, from 3.2 million to 5.7 million (Means 1998). In fact, in the early 1990s, the federal government spent nearly as much on housing assistance as it did on programs such as AFDC, SSI and Food Stamps and considerably more than it spent on EITC and JTPA (Blank 1997).

At the same time, high-rise public housing developments are one of the most striking symbols of urban decay and ghetto poverty in our society. Many critics argue that public housing has fostered racial and economic segregation (Massey and Denton 1993), increased crime and juvenile delinquency (Newman 1972), and reduced educational and employment outcomes for children and adults (Ong 1998). Recent accounts have vividly portrayed the poverty, violence, and despair endemic in inner-city public housing (Kotlowitz 1991).

As a result of these factors, there has been a national shift toward providing low-income renters with vouchers to purchase housing on the private market, rather than providing assistance through housing projects. Between 1977 and 1997, the number of households receiving housing vouchers increased from 162,000 to over 1.4 million, which comprised over one-third of all lowincome renters served by HUD. In 1996, Congress passed Section 202 of the Omnibus Consolidated Rescissions and Appropriations Act (Section 202) that required housing authorities to conduct a viability assessment of their public housing stock. If the costs of rehabilitation and maintenance for a particular unit exceed the cost of providing the families in that unit with a rent 
subsidy for the private housing market for a period of 20 years, then the housing authority must remove the unit from its stock. Roughly 91,000 units across 35 public housing authorities are scheduled for demolition as a result of this legislation. In Chicago alone, 19,000 units in 17 developments failed the viability test (Gudhart-Powers 2000).

Despite these substantial policy changes, we know relatively little about the impact of public housing on the well being of poor families, let alone the impact of demolishing the traditional high-rises and shifting families to voucher-based assistance. Some evidence in the early seventies suggested that public housing fostered social dysfunction (Newman 1972), but recent work suggests that public housing participation does not have an adverse effect on longrun labor market outcomes (Oreopoulos 2001) and that children in public housing may actually have better educational outcomes than low-income children who do not live in public housing (Currie and Yelowitz 2000). While some studies have compared public housing residents and Section 8 participants, most fail to account for selection involved in Section 8 participation. Recent randomized housing mobility studies indicate that moving children from low-income housing projects to low-poverty neighborhoods leads to improvements in health and educational outcomes (Ludwig et. al. 2000; Katz et. al. 2001; Ludwig et. al. 2001). However, these studies include a small, select group of public housing residents that volunteered for the program.

A recent series of public housing closings in Chicago provide an excellent opportunity to study the effect of public housing in general as well as the impact of providing families with housing vouchers. During the 1990s, the Chicago Housing Authority (CHA) closed over 7,400 units of public housing in 12 developments. Residents in the affected buildings were offered Section 8 housing vouchers to move to private housing anywhere in the metropolitan area. The 
families affected by the closings did not volunteer to move, they were not provided with additional counseling or support, and they were not required to relocate to any particular area. In this paper, I examine the impact of recent public housing closings in Chicago on student achievement. To measure educational outcomes over time, I combine administrative data from the CHA and the Chicago Public Schools (ChiPS). I match students to housing developments through home addresses in school records and determine building closure from occupancy data provided by the CHA. To estimate the impact of public housing demolition, I compare students living in CHA units slated for closure with peers living in units in the same project that were not closed. To the extent that these groups were identical prior to closure, any subsequent differences in educational achievement can be attributed to the closure. While the CHA targeted projects for redevelopment on the basis of vacancy rates and physical deterioration, the timing of building closures within project is plausibly uncorrelated with unobservable student characteristics.

I find that the demolitions led to a small increase in the dropout rate among older children (i.e., youth age 14 and older at the time of the closure announcement), but had no impact on the academic achievement of younger children on a wide variety of outcome measures. This was true across various subgroups and did not appear to change substantially over time. In terms of relocation outcomes, I find that children affected by the closures were considerably less likely to be living in high-rise public housing in subsequent years but were still living in high poverty neighborhoods and attending schools identical to those of the control students. Indeed, even those students who did move to substantially better neighborhoods did not end up in significantly better schools. 
These results suggest that high-rise public housing does not have an independent impact on student achievement. ${ }^{1}$ This finding contradicts some of the earlier literature on public housing participation, but is consistent with the recent work by Currie and Yelowitz (2000) and Oreopoulos (2001). The finding that low-income families tend to relocate close to their original neighborhood is consistent with the MTO studies (Goering, J., J. Kraft, et al. 1999). In contrast to some of the initial results from MTO, however, I find that children whose families were offered Section 8 vouchers do not show improved achievement. One explanation for this difference involves the respective samples - families in MTO all volunteered for the program whereas the households in this study were forced to relocate. If the voluntary nature of the relocation is indeed important, it suggests that the current HUD policy initiatives to eliminate high-rise public housing will not necessarily lead to the benefits documented in the recent housing mobility experiments such as MTO.

The remainder of this paper is structured as follows. Section 2 provides background on federal housing assistance programs and reviews the prior literature on housing voucher programs. Section 3 outlines my empirical strategy. Section 4 describes the recent history of public housing in Chicago and Section 5 describes the data used in this study. Sections 6 presents the main reduced form results. Section 7 looks more carefully at the impact of public housing participation on student outcomes. Section 8 concludes.

\footnotetext{
${ }^{1}$ Below I argue that the dropout effect for older children was largely a result of the initial disruption generated by the relocation. For younger children, it is possible that benefits associated with the relocation opportunity may have been offset by negative effects of the move itself, although the results in Table 4 suggest that this is not the case.
} 


\section{Background}

\section{Conceptual Framework}

The relocation opportunity provided by the demolitions might influence educational outcomes through several different mechanisms (see Figure 1). First, the relocation opportunity may allow families to move to lower poverty neighborhoods. There are a number of theories linking residential location to individual outcomes, emphasizing factors such as peer effects, social networks and local public goods (Jencks and Mayer 1990; Brooks-Gunn, Duncan et al. 1997. There is an extensive literature documenting the association between neighborhood or school characteristics and individual outcomes (Ellen and Turner 1997; Jargowsky 1997), including randomized housing mobility experiments that provide strong evidence of a causal impact of neighborhood poverty on a variety of outcomes (Katz et. al. 2001; Ludwig et. al. 2001).

Second, relocation may raise the quality of a child's school. While there is some controversy over which (if any) observable school or teacher characteristics are associated with student achievement, there is strong evidence that some schools and teachers are more effective than others (Hanushek 1986, 1992; Rivkin et. al. 2001, Rockoff 2002). Even a modest change in neighborhood quality might be associated with substantial improvements in school performance if the move leads to a change in the school attendance area. ${ }^{2}$

Third, regardless of the distance of the move, Section 8 relocation allows households to leave public housing, which may influence educational outcomes. Sociological theory based on the notion of "defensible space" contends that the physical characteristics of high-rise public housing (i.e., centralized elevator banks, long corridors and multiple entries) foster criminal behavior and other social problems, although the evidence to support this hypothesis is mixed 
(Newman 1972; Newman and Franck 1980; Roncek, Bell et al. 1981; Farley 1982; Dunworth and Saiger 1994; Holzman 1996). In fact, one study in Chicago found a relationship between public housing, increased criminal behavior and decreased employment rates in census tracts with high-rise developments, but found no such relationship in tracts with low-rise developments (Condon 1991). Alternatively, public housing may provide benefits that are not available to lowincome families in private housing, including adequate quality housing, greater access to social services and a close network of friends and family. Several recent studies that address the endogeneity of public housing participation suggest that public housing has either a zero or even small positive effect on outcomes (Newman and Harkness 1999; Newman, Harkness et al. 1999; Currie and Yelowitz 2000, Reingold, Ryzin and Ronda 2001).

While living in private housing in better neighborhoods and attending better schools may increase academic achievement, some evidence suggests that the disruption of the move itself may have a negative impact on school performance, particularly in the short-run. There is a substantial literature that documents the negative association between school mobility and student achievement (Ingersoll, Scamman et al. 1989; Alexander, Entwisle et al. 1994; Kerbow 1996).

\section{Prior Literature}

The earliest evidence on housing vouchers comes from the Experimental Housing Allowance Program (EHAP), a massive, federally funded social experiment during 1970s. In a comprehensive review of EHAP findings, Struyk (1981) concluded that housing allowances neither increased mobility nor affected racial or economic segregation. More recent studies show that participants in tenant-based assistance live in less highly concentrated poverty areas

\footnotetext{
${ }^{2}$ This is only one mechanism that could generate non-linear neighborhood effects.
} 
and have higher employment rates. However, these studies also highlight important exceptions to the aggregate association between vouchers and neighborhood quality, emphasizing that inner-city and minority voucher recipients tend to relocate in highly segregated and relatively high poverty areas that are close to their neighborhood of origin (Goering, Stebbins et al. 1995; Hartung and Henig 1997; Newman 1997; Turner 1998; Turner, Popkin et al. 1998; Cunningham, Sylvester et al. 1999). For example, Fischer (1999) found that almost 80 percent of relocated families in Chicago moved to census tracts that were over 90 percent black and that 90 percent moved to areas with median incomes under $\$ 15,000 .^{3}$

These findings have generated increasing interest in mobility assistance programs. ${ }^{4}$ The most well-known housing mobility program — the Gautreaux Program in Chicago- resulted from a lawsuit brought against the CHA and HUD in the early 1970s that charged the agencies with violating the civil rights of tenants by pursuing racially discriminatory housing practices. As part of a settlement in the Gautreaux case, HUD and CHA established a program that provided public housing residents with Section 8 vouchers to move to private housing in Chicago or nearby suburbs. Since 1976, more than 5,000 families have participated in this program and more than half moved to middle-income white suburbs (Rosenbaum 1995). In a series of studies, Rosenbaum and his colleagues compared the educational and employment outcomes of households that moved within the city ("urban movers") to those who moved to the suburbs ("suburban movers"). Kaufman and Rosenbaum (1992) found that children of suburban movers consistently and substantially outperformed the children of urban movers.

\footnotetext{
${ }^{3}$ Popkin and Cunningham $(1999 ; 2000)$ list a number of barriers to successfully leasing an apartment in the private market, including costs (of transportation, credit checks, security deposits), limited time to search, large family sizes (which limit apartment options), personal problems (lack of communication skills, substance abuse, criminal backgrounds, illness, disability) and landlord discrimination.

${ }^{4}$ Today there are 54 mobility programs in 33 different metropolitan areas (Turner 1998; Turner, Popkin et al. 1998).
} 
While the Gautreaux experiment illustrates the potential benefits of residential relocation, because participants were not randomly assigned to urban or suburban locations, it is possible that neighborhood effects may be confounded with unobserved participant characteristics. Moving to Opportunity (MTO), a randomized housing-mobility experiment funded by HUD in five cities, attempts to address these concerns. Low-income families who lived in public housing were randomly assigned to one of three groups: (i) an experimental group (MTO group) which received housing subsidies and search assistance to move to private-market housing in tracts with poverty rates below 10 percent; (ii) a comparison group that received Section 8 housing vouchers with no constraint on relocation choice (Section 8 group); and (iii) a control group that received no special assistance.

Preliminary results from the MTO program indicate substantial benefits of housing mobility, particularly relocation to low-poverty areas, for children (Goering, Kraft et al. 1999; Leventhal and Jeanne 2000; Ludwig et. al. 2000; Rosenbaum and Harris 2000; Katz et. al. 2001; Ludwig et. al. 2001). Studies in all sites found that the experimental and comparison groups moved to lower poverty areas compared to controls, with the most dramatic differences for the MTO group. Several studies found improved physical and mental health of mothers and children in the MTO group, increased feelings of safety and satisfaction with neighborhood and school, and decreased problem behavior among children. Ludwig et. al. (2001) found that the offer to relocate families in Baltimore from a high- to low-poverty neighborhood reduced juvenile arrests for violent crime by 30 to 50 percent, though there is some evidence of an increase in property crime among this group. Similarly, Ludwig et. al. (2000) found that the opportunity to move from high- to low-poverty neighborhoods increased math and reading scores by roughly onequarter of a standard deviation. The opportunity to move using traditional Section 8 vouchers 
generated some positive impacts on reading outcomes, but no impact on math scores. Katz et. al. (2001) found that the households in the Boston MTO demonstration that were offered vouchers experienced significant improvements in health and safety and declines in problem behavior among boys.

An important feature of most Section 8 programs including Gautreaux and MTO is that they involve voluntary relocation. Only a few studies examine forced relocation. In one such study, Varady and Walker (2000) examined households that received Section 8 vouchers to leave distressed developments in four cities (Baltimore, Newport News, VA, Kansas City, MO, and San Francisco). They found that the majority chose to remain in the same neighborhood and thus continued to live in racially segregated neighborhoods, though participants did move to census tracts with somewhat higher median household income.

\section{The Empirical Strategy}

In order to identify the impact of the demolitions on student outcomes, we must find a suitable counterfactual. As Table 1 shows, we cannot reasonably compare students whose buildings were closed or demolished to the average ChiPS student because students in public housing are systematically different than their peers. For example, over 90 percent of students in public housing receive free lunch compared with 72 percent of the entire student population. Public housing students live in census tracts with poverty rates roughly three times higher than other students, attend schools with substantially fewer high performing peers, score 12 percentage points lower on standardized math and reading exams, and miss 60 percent more days in high school than other students. Figure 2 shows that the public housing developments where demolitions took place are located in more disadvantaged neighborhoods than other 
public housing developments, which is consistent with the fact that CHA's redevelopment efforts focused on the most distressed developments.

Instead, I compare students who were living in buildings slated for demolition immediately prior to the closure announcement with students living in buildings in the same project that were not slated for demolition. Let $\mathrm{y}$ be some outcome, $\mathrm{D}$ be an indicator for living in a building subject to demolition, and $\mathrm{X}$ be a vector of individual background variables (including an intercept). The demolition impact is thus captured by the $\pi_{1}$ coefficient in the ordinary least squares (OLS) regression

$$
y_{i j t}=D_{i j t} \pi_{1}+\gamma_{j}+\delta_{t}+\varepsilon_{1 j i t}
$$

where $\mathrm{i}, \mathrm{j}$ and $\mathrm{t}$ index individuals, projects and time respectively, $\gamma$ and $\delta$ are fixed effects for project and year respectively, and $\varepsilon$ is a stochastic error term.

The key assumption required for consistent estimation of $\pi_{1}$ is that the demolitions were not correlated with unobserved factors that may influence student achievement directly - i.e., $\operatorname{Cov}\left(D_{i j t}, \mathcal{E}_{1 i j t}\right)=0$. In the following sections, I present evidence suggesting that this assumption is met here. More specifically, I show that students in demolished and non-demolished buildings appear identical on a wide range of observable characteristics immediately prior to the closure announcement. In addition, I discuss the history of the building closures, along with the process of tenant assignment and transfer in the CHA, all of which suggest that the demolitions examined in this paper were plausibly uncorrelated with other unobservable student characteristics. However, including additional covariates (X) allows one to satisfy a slightly weaker condition, $\operatorname{Cov}\left(D_{i j t}, \varepsilon_{1 j i t} \mid X_{i j t}\right)=0$, and reduces the residual variation in (1), thereby increasing the precision of the demolition estimate. For this reason, the main estimates presented in the paper will come from the following specification: 


$$
y_{i j t}=D_{i j t} \pi_{2}+X_{i j t} \beta_{2}+\gamma_{j}+\delta_{t}+\varepsilon_{2 i j t}
$$

An additional concern arises from the fact that the primary outcome measures - e.g., test scores, grades and retention - are not observed for students who drop out or otherwise leave the ChiPS. If this sample attrition is correlated with the demolitions, it may bias the achievement estimates. The assumption required for consistent estimation of $\pi_{2}$ is that $\operatorname{Cov}\left(M_{i j t}^{y}, \varepsilon_{2 i j t} \mid X_{i j t}\right)=0$ where $M_{i j t}^{y}$ is a binary indicator of whether outcome y is missing for individual $\mathrm{i}$ at time $\mathrm{t}$. In the following sections, I show that the demolitions have no statistically significant effect on transferring out of the ChiPS, being enrolled in school, or having valid achievement data, suggesting that the achievement estimates are not biased by differential sample attrition.

Assuming that the above assumptions are met, the coefficient $\pi_{2}$ will reflect the causal impact of public housing demolitions on educational outcomes. This effect sheds light on the potential impact of the future demolitions in Chicago and similar building closures taking place in urban areas throughout the country as a result of the recent federal legislation. From a program evaluation perspective, therefore, $\pi_{2}$ is the key parameter of interest.

As discussed in the previous section, however, the demolition effect may operate through several different mechanisms and thus may be thought of as a reduced form estimate. To explore the importance of these pathways, I estimate variations of equation (2) in which the dependent variables are relocation outcomes such as mobility, public housing participation, neighborhood poverty and school quality. I present the both reduced form estimates - on education and relocation outcomes - in Section 6. Under certain conditions, the demolitions may identify a parameter of more general interest - i.e., the impact of public housing itself. In Section 7, 
therefore, I discuss how one might scale the reduced form estimates to measure the impact of public housing participation on student achievement.

\section{Public Housing in Chicago During the 1990s}

The Chicago Housing Authority (CHA) was organized in 1937 to provide temporary housing for people unable to obtain "decent, safe and sanitary dwellings" in the private market. Today public housing residents represent roughly 4.7 percent of the city's population, making the CHA the third largest housing authority in the nation. The largest component of the CHA consists of 17 federally funded developments that primarily serve families with children, including 28,335 units with 50,526 residents (CHA 2000a).

The public housing closings that took place in Chicago during the past decade were not part of a unified plan, but rather the result of a variety of events and initiatives, some purposeful and others unforeseen. ${ }^{5}$ Reasons for the closures range from a desire on the part of the CHA to remove or rehabilitate unsafe buildings to initiatives of private developers to build new market rate and mixed-income housing in gentrifying neighborhoods. Some of the earliest building closures and demolitions stemmed from a court case filed on behalf of residents in the Henry Horner Homes. In 1991, the National Center on Poverty Law filed suit against the CHA on behalf of the Henry Horner Mothers' Guild and individual residents, claiming that the CHA and HUD violated the United States Housing Act by failing to maintain the Horner developments as “decent, safe, sanitary and otherwise habitable." The consent decree signed by the CHA in 1995 called for a comprehensive revitalization of Horner, which entailed the demolition of a many mid- and high-rise buildings (Zagel 1995).

\footnotetext{
${ }^{5}$ In contrast, the more recent building closures and demolitions in Chicago have been carefully laid out in advance as part of the "plan for transformation" in Chicago's public housing system (see CHA 2000b).
} 
While many of the closures and demolitions have taken place as part of a federally funded redevelopment initiative known as the HOPE VI program, the most widely publicized closures have been in response to crises. The Cabrini-Green development, plagued by gang violence in the 1980s, attained national notoriety as a result of the shooting death of a seven-year old boy, Dantrell Davis, on his way to school on October 13, 1992. This spurred the mayor and the CHA to vacate several of the Cabrini high rises, which were later demolished in 1995 (Hawes 1992; Nickerson 1992). In January 1999, pipes burst in several of the Robert Taylor high rises, causing flooding and leaving residents in those buildings without heat in the middle of a major snowstorm. CHA was forced to evacuate over a hundred families in four buildings, placing them temporarily in local hotels and churches before permanently relocating them (Garza 1999; Garza 1999; Jackson and Garza 1999).

Families that were required to relocate were given the option to either (1) transfer to another unit within their current development, (2) transfer to a unit in another CHA development (contingent on availability), or (3) receive a Section 8 voucher. If a family chose the Section 8 option, the CHA paid for moving expenses as well as the cost of transferring telephone, electricity and other utilities.

While providing an opportunity to leave public housing, the building closures that took place in Chicago during the 1990s differed considerably from the randomized housing mobility experiments such as Gautreaux and MTO. First, participants in the earlier housing mobility experiments were not only volunteers, but were likely a select group of public housing residents since they had to meet certain requirements in order to participate in the program. ${ }^{6}$ Second, Chicago families were not required to relocate to low-poverty neighborhoods, as was the case for

\footnotetext{
${ }^{6}$ For example, the Gautreaux program only selected families with four or fewer children, who paid their rent regularly, had some source of income (usually AFDC) and met acceptable housekeeping standards.
} 
the experimental groups in Gautreaux and MTO. ${ }^{7}$ Finally, the Chicago families received considerably fewer support services than the experimental families in Gautreaux and MTO. ${ }^{8}$

\section{The Data}

The data for this study is drawn from administrative records of the Chicago Public Schools (ChiPS) and the Chicago Housing Authority (CHA). Administrative data from the ChiPS includes student records for each semester that a student was enrolled in a ChiPS school from 1991-92 to 2001-2002. These records indicate a student's school, grade, and home address along with other information such as race, gender, legal guardian, and special education status. For younger children, I focus on math and reading achievement as measured by the Iowa Test of Basic Skills (ITBS), a standardized, national norm-referenced exam taken by nearly all ChiPS students in grades one to eight. Achievement results are presented in terms of national percentile ranks, where the comparison group is a national sample of students in the same grade level. ${ }^{9}$ For older children, I examine high school attendance, grades and course credits as well as attainment measures such as whether a student dropped out of school. While these data have detailed information about educational outcomes, they do not include information on other outcomes such as employment, earnings or juvenile delinquency. Appendix A provides a more detailed discussion of the construction of the variables used in this analysis.

Administrative data from the CHA lists all public housing developments in the city, including building addresses and the number of units per building. Using student addresses in

\footnotetext{
${ }^{7}$ Certain groups in the mobility experiments - the urban movers in Guatreaux and the Section 8 control group in MTO - were not required to move to low-poverty neighborhoods. There is some evidence that these groups benefited relative to non-movers though not as much as the families who moved to low-poverty neighborhoods.

${ }^{8}$ The average cost to counsel each experimental family in Gautreaux and MTO was $\$ 555$ and $\$ 1,455$ respectively (Goering, Kraft et al. 1999). While I was not able to obtain comparable figures for the Chicago relocations, CHA officials indicated that the cost was substantially less than standard housing mobility programs.

${ }^{9}$ The results are comparable for grade equivalents, normal curve equivalents and standardized scores as well.
} 
school records, I merge the ChiPS and CHA data to determine whether a student was living in public housing at a particular time. The full data set is thus a nearly complete census of ChiIPS students who lived in public housing during at least one semester between 1991-1992 and 20012002. This includes 94,666 students who lived in 2,180 buildings ${ }^{10}$ in 36 developments during this period.

The sample used in this analysis is a sub-sample of the full data set. First, I restrict the analysis to "family developments" owned and operated by the CHA, thereby excluding individuals who live in senior-citizen developments or scattered site public housing as well as those who live in private housing but receive Section 8 vouchers. Second, I consider only students living in high-rise buildings ${ }^{11}$ in developments that experienced closings or demolitions over this period. I exclude developments that did not experience any building closings for two reasons: (1) Table 1 suggests that the children in these developments may differ systematically from those in the developments that experienced closings; (2) Since I include fixed development effects in the statistical model, information on students in unaffected developments will not help estimate the treatment effect. ${ }^{12}$ I exclude low- and mid-rise buildings because in general these buildings did not experience the same type of full-scale closure or demolition that high-rises did, but were rather vacated more slowly over a longer period of time. Third, I do not consider building closures that were announced prior to 1993 because the school records do not extend

\footnotetext{
${ }^{10}$ Note that a building may contain several different addresses. CHA defines a building as a structure with a continuous roof.

${ }^{11}$ Following the standard practice of the CHA, I define a high rise as any building with at least 75 units.

${ }^{12}$ Because I include fixed development effects, the treatment effect of closure is only estimated off of the variation within developments that experienced some treatment. While the other observations help identify the other coefficients in the model, the inclusion of these cases does not change the primary results so I have chosen to omit these observations.
} 
back far enough to track these students. ${ }^{13}$ Fourth, I exclude cases where (a) there is good reason to believe that the demolition may have been correlated with unobservable tenant characteristics that also influence achievement (e.g., the three buildings in the Robert Taylor Homes commonly referred to as "The Hole" that were demolished in 1997 as a result severe and persistent gang problems) or (b) students in demolished buildings appear substantially different on observable characteristics than students in non-demolished buildings. Fifth, since over 95 percent of public housing residents in Chicago are African-American, I have chosen to limit my analysis to these students. Finally, I drop observations that were missing demographic information (less than one percent of the sample).

I create a panel in which each observation corresponds to a student-year, yielding a maximum of 11 observations per student. Note that the observations are based on school enrollment, so that a student in the ChiPS from 1992 to 2002 would have 11 observations, although she may have lived in public housing for as little as one semester or as long as 11 years. Students who entered school after 1992 or left school prior to 2002 will have fewer than 11 observations.

To construct treatment and comparison groups, I first select a base group of students who were living in a public housing development in the year prior to notification of a building closure. More specifically, if a building closure was announced in the 12-month period between November $1^{\text {st }}$ in year one and October $31^{\text {st }}$ in the following year, the "base group" consists of all students who were living in the development in October of year one. ${ }^{14}$ Students who were living in the buildings scheduled for closure comprise the treatment group while students in other stable

\footnotetext{
${ }^{13}$ School records are available as far back as 1992, but in the case of some of the earliest building closures, it appears that families had begun vacating building prior to this date. Consequently, the number of students who report living in these buildings in 1992 or 1993 is extremely small.

${ }^{14}$ This structure is chosen because the school records contain addresses as of October for each academic year.
} 
buildings (defined as those buildings that were not closed between 1992 and 2002) serve as the comparison or control group. The final sample consists of 10,556 students in 73 buildings in 9 developments. The treatment group consists of 3,526 students living in 31 buildings slated for demolition. Appendix B describes the process used to determine the notification and closure dates and Appendix $C$ provides more details on the construction of the sample.

\section{How Did Treatment and Control Students Compare Prior to the Closings?}

Table 2 compares treatment and control students within housing development in the year prior to the closure announcement by regressing each of the dependent variables on a dummy variable for treatment group along with fixed effects for development and year, as in equation (1). If the demolitions were randomly assigned, then we would expect that none of the coefficients in column 2 would differ from zero, except for sampling error. Indeed, this condition appears to be largely true. Only 1 out of the 18 coefficients is significantly different than zero - children in treatment buildings were 0.32 years younger than their peers in control buildings. While the difference is statistically significant, it is quite small given the standard deviation of age in the sample is roughly 4.02 . For all of the other characteristics, the coefficients are substantively small and statistically insignificant. Treatment and control students appear identical in terms of background characteristics such as family composition (living in foster care), socio-economic status and neighborhood poverty as well as measures of cognitive ability and school performance such as math and reading achievement, special education placement, GPA and credit accumulation. ${ }^{15}$

\footnotetext{
${ }^{15}$ Note that the estimates for the achievement outcomes include a full set of fixed effects for current grade level to account for the age differences between treatment and control students. The results are identical if one includes age effects instead of grade effects. These effects were included primarily to account for potential differences in the achievement exams across grades. Interestingly, in none of the cases does the inclusion of grade or age effects change the inferences, which suggests that the exams were well equated across grade (as the test publisher claims).
} 
Even in the absence of observable differences, however, the two groups may differ along unobservable dimensions. If the least motivated or capable families were more likely to live in buildings scheduled for demolition, for example, we might expect the treatment group children to have worse outcomes in the absence of the public housing closings, thus biasing the estimated demolition effect downward. In order for a comparison of treatment and control students to yield unbiased estimates of the treatment effect, either (a) families must have been randomly assigned to units within development (or in a manner uncorrelated with factors that may influence achievement), or (b) buildings within a project must have been selected for demolition for reasons uncorrelated with unobserved tenant characteristics that influence student achievement. While it is impossible to completely rule out the possibility of unobservable differences, the processes of tenant assignment and recent building closures in Chicago suggest that such differences are unlikely. With roughly 30,000 families on the waiting list for CHA housing, waiting times of seven to eight years for public housing in Chicago are not uncommon. When families reach the top of the list, they are assigned units based on bedroom size and availability. Prospective tenants can reject an offer and place their name on a waiting list for a particular development, but this rarely occurs in practice because the site-specific waiting lists are often longer than the general CHA list. Because of the high demand for public housing services and the physical deterioration of many buildings, there are almost no transfers for reasons other than building closure or rehabilitation (Russ 2000).

Closure decisions were clearly linked to the physical condition of the buildings, although the relationship was not always straightforward. For example, all of the Robert Taylor high rises were built at the same time in the same style, are in similarly poor condition and all are slated for demolition over the next 15 years. However, the closures to date have been driven largely by 
chance events such as pipes bursting in one building rather than another. The comprehensive redevelopment plan devised for the Cabrini-Green development included plans for the demolition of high rises in the North extension, starting on the East side of the development simply because it was adjacent to the wealthier business district. A final example involves the Wells Extension mid rises. In the early nineties, the CHA intended to rehabilitate all 10 of the buildings, but ran out of money after completing six so that the remaining four mid rises had to be closed and demolished. According to tenants and CHA officials, there was no clear reason why the CHA chose to begin with those particular buildings.

Finally, I have explicitly excluded cases where there is good reason to believe that the demolition may have been correlated with unobservable tenant characteristics that could influence achievement. For example, I do not examine the relocation associated with the demolition of three buildings in the Robert Taylor Homes commonly referred to as "The Hole", which were closed in 1997 as a result severe and persistent gang problems. Similarly, I exclude the demolitions associated with closure of several high rises in Cabrini-Green following the highly publicized shootings in 1992.

\section{The Impact of Public Housing Closures}

Table 3 shows the effect of the public housing closures on sample attrition along with a variety of relocation and educational outcomes three years after the initial notification. Column 1 shows the control mean and standard deviation to facilitate interpretation of the magnitudes.

The remaining columns present estimates with varying controls. If the students were randomly assigned to treatment or control buildings, then we would not expect to see any differences between the estimates in columns 2 to 4 , which is generally the case. 
The top panel addresses the issue of sample attrition. We see that attrition rate was identical for students from demolished and non-demolished building, with roughly 6.1 percent of children leaving the ChiPS for a private school or moving out of the district. Among children younger than 14 years of age at the time of the closure announcement (the sample for whom most achievement measures are available), treatment and comparison students were equally likely to be enrolled in school three years later. More importantly, there is no difference in the likelihood of having missing test score or transcript data across the two groups. Hence, for the remainder of the paper, the achievement estimates will focus only on these younger students.

It appears that the demolitions had a small, negative effect on the educational attainment of older children in public housing (i.e., those 14 years or older at the time of the closure announcement). Older students in demolished buildings were roughly 4.4 percentage points $(8.2$ percent) more likely to have dropped out of school within three years than their peers in control buildings. Given the extremely high percentage of students in public housing in Chicago who eventually drop out of school, it is perhaps not surprising that the disruption generated by a building demolition and subsequent relocation increase the dropout rate.

In contrast, a comparison of educational outcomes among younger children indicates that the public housing closings had no statistically or economically significant impact on student achievement. Control students in public housing buildings that were not demolished scored at the $32^{\text {nd }}$ and $28^{\text {th }}$ percentiles in math and reading respectively. The point estimates in column 4 suggest that the demolition effect was only 0.2 and 0.1 percentile points for math and reading respectively, which corresponds to effect sizes of roughly $0.01{ }^{16}$ There was similarly little effect on high school outcomes. The point estimates for absences, course credits and GPA were extremely small (generally less than 0.05 standard deviations) and never statistically significant. 
How might one explain these results? As discussed earlier, there are several pathways through which the demolitions could operate including a change in public housing participation, neighborhood poverty or school quality. While I cannot tell exactly which families utilized Section 8 vouchers, school records allow me to determine where students were living and what schools they were attending. Using this information, the bottom panel explores the impact of the demolitions on a variety of relocation outcomes.

We see that students affected by the demolitions were significantly less likely to be living in public housing three years following the closure announcements. Interestingly, only 61 percent of control students were still living in public housing three years after the announcement, perhaps reflecting the healthy economy during the late 1990s or the anticipation of future demolitions. Still, living in a building slated for closure decreased the probability of living in public housing by roughly 20 percentage points, or 33 percent. While the difference is highly significant, the magnitude of the effect suggests that relatively few treatment families took a Section 8 voucher, choosing instead to transfer to another public housing unit. This finding is consistent with the earlier suggestions by Fischer $(1999,2003)$ and with the results of other housing mobility programs (e.g., approximately 50 percent of families in the MTO program utilized a voucher when given the opportunity. See Goering, Kraft et al. 1999).

While treatment students were more likely to move out of public housing, they relocated to neighborhoods relatively close to their original residence. After three years, these students were living on average only 1.25 miles further from their original residence than their peers in control buildings. While the average neighborhood poverty rate was somewhat lower for the treatment group (53 percent) than the comparison group (68 percent), it is important to note that treatment students were still living in very poor neighborhoods. Less than 3 percent of treatment

\footnotetext{
${ }^{16}$ This is based on student level standard deviations within grade level for all students in the ChiPS.
} 
students were living in low poverty tracts (i.e., lower than 10 percent poverty), and only 30 percent were living in moderate-poverty tracts (i.e., 10 and 40 percent poverty). Moreover, conditional on living in public housing, there was little difference in the census tract poverty rates of treatments versus controls. This suggests that the differences in neighborhood poverty are directly associated with leaving public housing - that is, families in demolished buildings did not take the opportunity to transfer to other public housing units in lower poverty neighborhoods. This is consistent with the Section 8 literature that suggests that inner-city public housing residents are unlikely to leave their neighborhoods without intensive support and/or a requirement to relocate to a low-poverty area.

As one would expect given the marginal changes in residential location, children from demolished buildings do not appear to be attending significantly different schools than their peers in non-demolished buildings. Treatment students were 17 percentage points ( 30 percent) more likely to have switched schools since the closure announcement. Among those students who had switched schools at least once, however, the treatment group did not change schools more often than the comparison group, suggesting that they did not experience ongoing disruption. Most importantly, three years after the closure notification, treatment and comparison students appear to be attending identical schools in terms of average peer achievement - i.e., both groups are attending schools in which approximately 27 percent of students met national norms in mathematics. ${ }^{17}$

\footnotetext{
${ }^{17}$ These schools are similar along other dimensions as well, including average reading scores, racial composition, size, etc.
} 


\section{The Impact of Closures Over Time}

The closures appear to have led to a small increase in the likelihood of dropping out among older youth, but to have had no impact on the academic achievement of other children. Insofar as the initial relocation and school changes were disruptive, however, one might expect the impact of the closures to vary across time. If there were initial negative effects followed by steady improvements, then one might speculate that the demolitions would result in improved achievement in the long-run.

To examine the effects public housing closings over time, Table 4 presents estimates of the treatment effects for the first five years after initial notification for a sample of students in buildings with closure notification in 1996 or earlier $(n=7,483)$. By restricting the sample in this way, composition changes are less likely to contaminate any trends. These results, however, are not directly comparable to the results presented in Table 3 since the latter included all students. ${ }^{18}$

The results shown in the top panel indicate that building closures did not have a significant impact at any point on the likelihood of students leaving the ChiPS. For younger students, enrollment rates and likelihood of missing achievement data are equal across treatment and control students throughout the five-year period. The second panel shows that the effect of closure on residential and school mobility rises in the first few years, but then levels off by year three. For example, one year following the notification treatment students were 10 percentage points less likely to be living in public housing than control students. ${ }^{19}$ This difference rose to roughly 20 percentage points in year two, but actually declined somewhat by years four and five.

\footnotetext{
18 To test the sensitivity of these results to the most recent demolitions, I re-estimated all specifications using as control students only those in buildings not scheduled for demolition until 2004 or later and found comparable results.

${ }^{19}$ The bottom two panels show the relocation and educational outcomes for younger children who remained in the ChiPS (i.e, did not drop out, transfer to private school or move out of the school district) for the entire five-year period $(n=3,889)$. The number of observations varies across the dependent variables because certain outcome variables are only applicable to elementary or secondary students.
} 
This pattern is repeated for census tract poverty rates and distance from initial residence. ${ }^{20}$ The impact on school quality does not change over this period - at no point do treatment students appear to be attending higher quality schools than comparison students.

For older children, the dropout effect seen in the baseline results appears to increase over the first few years but then level off by year four or five, reinforcing the notion that the relationship between demolitions and dropouts operates largely through the disruption associated with the initial relocation. For younger children, however, there is no statistically significant difference between the two groups at any point on any of the achievement measures. The fact that there is no trend in the achievement effects suggests that the disruption of the closures may not have had a significant influence the academic achievement of these children (perhaps not surprising given the other barriers already facing many children from low-income families in public housing).

\section{The Impact of Closure By Student Characteristics}

While public housing closures do not appear to have much of an effect on student outcomes in aggregate, it is possible that they may have significant effects for certain subgroups. Table 5 examines closure effects by gender, age and ability at the time of the announcement. ${ }^{21}$ With regard to gender, the building closures appear to have a larger effect on the likelihood of dropping out for girls than for boys. The demolitions increased dropout rates for girls by 5.7 percentage points or 12 percent compared with only 2.6 percentage points or 4 percent for boys (with the difference significant at the 5 percent level). On the other hand, there are no significant

\footnotetext{
${ }^{20}$ This may be due to treatment families were moving back into public housing, a phenomenon that occurred in the MTO program (Popkin, Harris and Cunningham 2001).

${ }^{21}$ Achievement results are not shown for children in the 14-21 age group because of the selection bias stemming from differential dropout rates.
} 
gender differences in the achievement effects for younger children. In fact, the point estimates for math scores suggest that girls may have fared slightly better than boys as a result of the demolitions. There is no clear pattern in the effects by age or prior achievement level. ${ }^{22}$ The demolitions appear to have increased dropout rates and absences more for high-achieving students, although the effect for math achievement was more positive among the top scoring group. In all cases, however, the point estimates for all groups are substantively small and the differences across subgroups are not close to significant at conventional levels.

\section{The Impact of Closure By Development}

Another reason that we might find few positive effects involves unobserved heterogeneity relating to the nature of the closings. Insofar as the public housing closings and demolitions over this period differed widely in both their underlying causes and the processes by which they were carried out, it is reasonable to expect that some of the closings may have benefited residents whereas the closings in other situations hurt the residents. Such a situation could lead to a zero average effect. For example, residents in buildings that were closed as part of planned redevelopment activities might have received more notice and thus been able to negotiate the relocation more successfully. Alternatively, residents that experienced emergency building closures may have been less likely to find another CHA unit for transfer and thus more likely to have left public housing.

Because there were a number of changes within the CHA during the 1990s, it is possible that the building closures were carried out differently depending on the year, and that these differences influenced the experiences of families. For example, by all accounts, CHA was in

\footnotetext{
${ }^{22}$ Prior achievement is measured by the average math and reading score in the year prior to the closure announcement. Because many children in the 14-21 age group did not take the exams in this year, we use an
} 
extreme disarray in the late eighties and early 1990s, both financially and administratively. HUD took control of CHA in 1995 and instituted a number of changes in the management and financial systems. In addition, the Section 8 program in Chicago was re-organized and contracted out to a private organization in 1995-96. By the end of the nineties, the City had assumed control of day-to-day operations in CHA, and the agency appeared to be running more smoothly than in the past. Given this history, it is likely that residents living in buildings closed in earlier years had fewer opportunities to relocate out of public housing with Section 8. In contrast, by the time the 1998-99 closings occurred, the Section 8 program for relocatees was well established, organized and known by all tenants.

To explore these potential forces, Table 6 examines the treatment effects across closure year and development. Columns 1 and 2 show the effect of the closings separately for closures announced in 1995-96 and 1998-99 respectively. Outcomes are measured three years after the announcement year. We see that children affected by the later closings were more likely to leave public housing and, consequently, relocated in slightly less impoverished neighborhoods in comparison to children affected by the earlier closings. This is consistent with the fact that the CHA and CHAC were better organized in the late 1990s. Also, it is consistent with the fact that many of the closures in 1998 were unplanned - e.g., the pipes bursting in Robert Taylor builidings in the 1998-99 winter. It is important to keep in mind, however, that in both cases, the treatment students were still on average living in highly impoverished neighborhoods relatively close to their original residence and neither the earlier nor later group appear to be attending significantly better schools as a result of the relocations.

Turning to the education outcomes, we see that the earlier demolitions significantly increased dropout rates while the later demolitions appear to have had no effect on the likelihood average of math and reading tests in prior years to impute a ability level for these students. 
of leaving school. Older children affected by the 1995-1996 closures were 6.7 percentage points more likely to drop out relative to their peers in control buildings whereas children affected by the 1998 closures appear no more or less likely to have dropped out than their peers. In contrast, there are no significant differences in the achievement effects for younger children in the earlier versus later closures.

Columns 3 and 4 show the results for demolitions that were planned and unplanned respectively. ${ }^{23}$ There is little difference in the relocation outcomes across these groups, suggesting that the speed of the closure did not play a large role in whether families were living in private housing in the long run. Similarly, there are no significant differences in the achievement effects across these groups.

\section{The Impact of Pubic Housing on Student Outcomes}

We have seen that the demolitions led to a small increase in the likelihood of dropping out among older students, but had no significant impact on the academic achievement of children under the age of 14. These reduced form estimates of public housing closures are useful from a policy perspective insofar as they shed light on the potential impact of the ongoing wave of public housing demolitions taking place across the country as a result of the recent federal legislation. However, the demolitions may also identify a parameter of more general interestthe impact of public housing on student outcomes.

Consider the following equation that relates some educational outcome (y) to an indicator for living in public housing $(\mathrm{P})$ and a vector of background characteristics (X)

$$
y_{i j t}=P_{i j t} \beta_{P}+X_{i j t} \beta_{3}+\gamma_{j}+\delta_{t}+\varepsilon_{3 i j t}
$$


where, as before, $\gamma_{j}$ reflects fixed effects for initial development and $\delta_{t}$ reflects fixed effects for announcement year. Here we specify $\mathrm{P}$ as the number of years the student lived in public housing during the four years from the beginning of the year in which the closure was announced to the end of the third year post announcement. Since X includes pre-announcement measures of student achievement, one can think of this equation as relating the number of years in public housing to the achievement gain over this period.

The typical concern is that OLS will yield biased estimates of $\beta_{P}$ because the years in public housing may be correlated with unobserved family or child characteristics that also influence academic achievement. However, because residents in demolished buildings were offered a voucher for housing assistance outside of public housing, the demolitions may serve as an instrument for public housing participation in our sample. This can be captured in the following first-stage equation:

$$
P_{i j t}=D_{i j t} \pi_{4}+X_{i j t} \beta_{4}+\gamma_{j}+\delta_{t}+\varepsilon_{4 i j t}
$$

where $\mathrm{D}$ is an indicator for whether a student was living in a building slated for demolition at the time of the closure announcement. In order for the demolitions to be a valid instrument for public housing, they must be correlated with the endogenous regressor (i.e., participation in public housing), but not directly correlated with the outcome of interest (i.e., student achievement). The demolitions clearly satisfy the first criteria. We saw in Tables 3 and 4 that students in demolished buildings were significantly less likely to be living in public housing in each year following the closure announcement.

\footnotetext{
${ }^{23}$ For the purpose of this analysis, planned closures are defined as those in which there was at least one year between notification and vacancy. This definition is broadly consistent with the reports of CHA residents and officials.
} 
As for the second criteria, we argued that the quasi-random nature of the demolitions suggests that building closures were plausibly uncorrelated with unobserved child or family characteristics that may independently influence educational outcomes. Even if the demolitions were uncorrelated with unobservable student characteristics, however, the earlier discussion suggests that demolitions might influence student outcomes through several different pathways. Strictly speaking, this means that in order for the demolitions to be a valid instrument for public housing participation, the mobility, neighborhood, school and relocation pathways shown in Figure 1 must have a zero effect. In the previous section, we saw that children from demolished buildings were attending virtually identical schools as their peers in control buildings, suggesting that school factors could not have contributed to the demolition impact. The comparison of short- and long-run demolition effects in Table 4 indicates that the impacts did not change much over time, suggesting that the initial disruption or relocation effects had little effect on student achievement.

On the other hand, the demolitions did result in a modest decline in neighborhood poverty, although this change was largely associated with a shift from extremely high poverty tracts (e.g., 70 percent) to only high poverty tracts (e.g., 55 percent). If such changes in neighborhood poverty improve educational outcomes, then one might worry that the IV estimates of $\beta_{P}$ will be biased downward, and therefore overstate any negative effects of public housing. Insofar as I find small and insignificant negative effects, this bias simply reinforces the conclusion that public housing itself has little if any effect on academic achievement. ${ }^{24}$

\footnotetext{
${ }^{24}$ Alternatively, one might simply choose to interpret the IV estimates as the impact of public housing participation (i.e., one's physical housing structure) and the associated poverty in the immediate neighborhood. In Chicago, many of the high-rise public housing developments comprise entire tracts, making it impossible to distinguish between exiting public housing and changing tracts and therefore neighborhood poverty. Moreover, in the present study, the decrease in neighborhood poverty was driven almost entirely by the transfer out of public housing - conditional on
} 
More generally, it is useful to note that instrumental variable strategy discussed here is simply a way to scale the reduced form effects presented earlier. In housing mobility studies such as MTO, researchers generally estimate the reduced form effect of being offered a housing voucher (similar to the net demolition effect estimated in this study), which is referred to as the "Intent-to-Treat" (ITT) effect. They then scale this effect by the proportion of families utilizing the voucher, yielding an estimate referred to as the "Treatment-on-the-Treated" (TOT), which reflects the impact of actually using the housing voucher to relocate. Because I do not have direct information on voucher use in this data, I have chosen to scale directly by a measure of public housing participation. ${ }^{25}$

Table 7 presents estimates of the impact of public housing on educational outcomes. While the OLS estimates suggest that living in public housing has no effect on student performance, they may be biased for several reasons. On one hand, families whose income increased over this period may have been able to leave public housing, in which case one might think that the estimates are biased upward. On the other hand, families who were evicted from public housing (e.g., for drug violations) or who were more mobile likely spent less time in public housing as well, which might be expected to bias the estimates downward.

However, the 2SLS estimates that use the exogenous variation in public housing participation generated by the demolitions also suggest that public housing participation has no

whether an individual was living in public housing, the demolitions only led to a 3 percentage point decline in neighborhood poverty rates - as opposed to transfers to other public housing in lower poverty areas.

${ }^{25}$ I could have chosen to instrument for neighborhood poverty as well, but chose to scale by public housing choice because that was the relevant choice variable. In a program evaluation framework, the 2SLS estimate of $\beta_{P}$ captures the effect of the "Treatment-on-the-Treated" (TOT), where the treatment is defined as the use of a Section 8 voucher to leave public housing. The corresponding Intent-to-Treat (ITT) effect, $\pi_{2}$, measures the effect of offering public housing residents the opportunity to relocate with Section 8 . The TOT simply scales this estimate by the proportion that received the treatment. The assumption required to estimate the TOT (identical those required for the IV estimation) is generally expressed as the requirement that the treatment must not have any impact on the 
significant effect on student achievement. The coefficient on the demolition indicator in the first stage regression is -0.600 with a standard error of 0.037 and corresponding F-statistic of 263.1 $(\mathrm{p}<0.000)$. This suggests that students in demolished buildings lived in public housing on average 0.6 fewer years than students in control buildings.

never-takers (i.e., those who were assigned to a treatment group, but chose not to receive the treatment) (Katz et. al. 2001). 
The point estimates suggest that each additional year spend it public housing is associated with a decline of 0.33 and 0.16 percentile points on the math and reading exams respectively. To gain a sense of the magnitude of the effects, recall that the average math score was 31.8 with a standard deviation of 24.9 in the third year after the closure announcement (and the standard deviation of the annual gain for this year was roughly 19.1 points). ${ }^{26}$ Insofar as these estimates may overstate any negative effects of public housing, the results suggest that public housing certainly does not have a substantial negative impact on educational outcomes. Given the precision of the 2SLS estimates, we can rule out achievement effects of roughly $+/-2.5$ percentile points (or 0.1 standard deviations) per year in either direction. While this is a fairly large effect, it may be informative given that the high-rise public housing developments included in the sample, such as the Robert Taylor Homes, are regarded as among the worst projects in the country. Nonetheless, it is important to recognize that these estimates cannot rule out smaller (positive or negative) effects of public housing. Because of the considerably smaller sample sizes, the estimates for the high school transcript outcomes are even less precise. Note, however, that the direction of the point estimates does not suggest a consistent positive or negative effect of public housing. ${ }^{27}$

\footnotetext{
${ }^{26}$ In terms of standard deviation units, if we standardize within grade level, the point estimates for math and reading are -0.022 and -0.014 .

${ }^{27}$ The models for high school transcript outcomes are specified slightly differently than the other achievement outcomes. Because the dependent variables - absences, course credits and GPA - refer to high school outcomes in the third year following the closure announcement, the independent variable for public housing participation in these models is a binary indicator of whether the student was living in public housing during this academic year (rather than the number of years in public housing since announcement). The coefficient on the demolition indicator in the first stage regressions for these models is -0.197 with a standard error of 0.032 and corresponding F-statistic of 36.6 $(\mathrm{p}<0.000)$, which coincides with the 20-percentage point effect shown in Table 3.
} 


\section{Conclusion}

This paper examines the impact of public housing demolitions on educational outcomes.

I find that the demolitions in Chicago during the 1990s led to a small increase in the likelihood of dropping out among older students, but had no significant impact on the academic achievement of children under the age of 14 . These results suggest that demolishing public housing and providing households the option of using housing vouchers to relocate to different neighborhoods will not necessarily produce better (or worse) educational outcomes for poor children.

Consistent with recent housing mobility experiments such as MTO, I find that a large proportion of families did not take advantage of the relocation opportunity provided by public housing closings to move to a substantially different neighborhood, and even those children who did move to substantially better neighborhoods did not end up in significantly better schools. ${ }^{28}$

On the other hand, these findings suggest that it may not be appropriate to generalize some of the benefits documented in housing mobility experiments such as Gautreaux or MTO to the general population of low-income households. The reduced form estimates suggest that children whose families were offered housing vouchers do not exhibit the same improvements in academic performance as children in the MTO Section 8 group. One reason for this difference may be that families affected by the demolitions in Chicago were not volunteers who sought out the housing voucher opportunity. ${ }^{29}$

\footnotetext{
${ }^{28}$ The reluctance of Section 8 families to leave familiar neighborhoods and the difficulty of relocating to low poverty areas is well documented in the Section 8 literature. In personal interviews with the author, public housing residents cited a variety of reasons for not choosing the Section 8 option, including the low quality of affordable housing in the private market, the additional expense of Section 8 (the program requires the resident to contribute up to 30-40 percent of their monthly income toward rent), the location and convenience of public housing, the existing network of friends in public housing, and the uncertainty of the Section 8 program.

${ }^{29}$ One alternative explanation involves the difference in cities. The MTO studies documenting benefits for Section 8 Comparisons focus on Baltimore and Boston, cities with different housing markets, patterns of residential segregation and public housing quality. I thank Jeff Kling for suggesting this possibility.
} 
The findings from this study also shed light on the impact of public housing on educational outcomes. Specifically, these results provide support for the Currie and Yelowitz (2000) finding that public housing does not have an independent negative impact on student performance. While students impacted by the closures did not move far from their original neighborhoods, they were considerably less likely to live in public housing following the closures. Yet these students had no better educational achievement and attainment than comparable peers who were living in buildings not directly impacted by the closures and were thus more likely to continue living in public housing. This is particularly noteworthy since unlike the Currie and Yelowitw (2000) study, which included a cross-section of public housing, the sample in this study includes what is considered the worst public housing in the country. ${ }^{30}$

In conclusion, it is worthwhile noting that while it appears that the public housing closures in Chicago did not academically benefit children in public housing, they may have influenced other youth or adult outcomes such as employment or criminal activity. Moreover, the redevelopment might be desirable for a number of other reasons, including the removal of unsafe dwellings, the construction of new, mixed-income developments and the economic growth associated with the redevelopment. More research is needed to determine the consequences of dismantling the system of high-rise public housing that has been such a large a part of social welfare policy in this country for the past half-century.

\footnotetext{
${ }^{30}$ Insofar as this study examined the impact of relatively short-term changes in public housing participation (i.e., from one to five years), it is still plausible that long-term exposure to public housing (e.g., growing up for 10 or 15 years in a public housing development) has a substantial impact on educational outcomes. However, Oreopoulos (2001) finds that there are no long-run labor market consequences of growing up in a poor neighborhood.
} 


\section{References}

Alexander, K. L., D. R. Entwisle, et al. (1994). Children in Motion: School Transition and Elementary School Performance. American Sociology Association, Los Angeles, CA.

Blank, R. (1997). It Takes a Nation. Princeton University Press, Princeton, NJ.

Brooks-Gunn, J., G. J. Duncan, et al. (1997). Neighborhood Poverty: Context and Consequences for Children. New York, Russell Sage Foundation.

CHA (2000a). Chicago Housing Authority Home Page, Chicago Housing Authority.

CHA (2000b). "Chicago Housing Authority: Plan for Transformation." January 6, 2000. http://www.thecha.org/Agency\%20Plan/agencyplan_year1.html.

Condon, M. (1991). Crime, Public Housing and Employment among Blacks in Chicago. Cambridge, M.A., Malcolm Weiner Center for Social Policy, Kennedy School of Government, Harvard University.

Cunningham, M. K., D. Sylvester, et al. (1999). Section 8 Families in the Washington Region: Neighborhood Choices and Constraints. Washington, D.C., Metropolitan Washington Council of Governments.

Currie, J. and A. Yelowitz (2000). “Are Public Housing Projects Good for Kids?” Journal of Public Economics 75: 99-124.

Deluca, S. (2000). Research Associate, Northwestern Univerity.

Dunworth, T. and A. Saiger (1994). Drugs and Crime in Public Housing: A Three-City Analysis. Washington, D.C., U.S. Department of Justice, National Institute of Justice.

Ellen, I. G. and M. A. Turner (1997). "Does Neighborhood Matter? Assessing Recent Evidence." Housing Policy Debate 8(4): 833-66.

Farley, J. E. (1982). "Has Public Housing Gotten a Bum Rap? The Incidence of Crime in St. Louis Public Housing Developments.” Environment and Behavior 14(4): 443-477.

Fischer, P. B. (2003). Where are the Public Housing Families Going? An Update. Unpublished manuscript. Lake Forest College, Lake Forest, IL.

Fischer, P. B. (1999). Section 8 and the Public Housing Revolution: Where Will the Families Go? Unpublished manuscript. Lake Forest College, Lake Forest, IL.

Garza, M. M. (1999). 9 High-Rises at Taylor Homes Slated to Close. Chicago Tribune. Chicago, IL: Section 2, Page 5. 
Garza, M. M. (1999). CHA Evacuates High-Rise Units Without Heat. Chicago Tribune. Chicago, IL: 1.

Goering, J., J. Kraft, et al. (1999). Moving to Opportunity for Fair Housing Demonstration Program: Current Status and Initial Findings. Washington, DC, Department of Housing and Urban Development.

Goering, J., H. Stebbins, et al. (1995). Promoting Housing Choice in HUD's Rental Assistance Programs. Washington, DC, U.S. Department of Housing and Urban Development.

Gudhart-Powers, J. (2000). Policy, Programs and Legislative Affairs, U.S. Department of Housing and Urban Development.

Hanushek, Eric A. (1992). "The Trade-Off between Child Quantity and Quality.” Journal of Political Economy. February 1992.

Hanushek, Eric A. (1986). "The Economics of Schooling: Production and Efficiency in Public Schools." Journal of Economic Literature, September 1986.

Hartung, J. M. and J. R. Henig (1997). "Housing Vouchers and Certificates as a Vehicle for Deconcentrating Poverty: Evidence from the Washington, DC, Metropolitan Area." Urban Affairs Review 32(3): 403-419.

Hawes, C. (1992). Now Things Move Quickly at Cabrini. Chicago Tribune. Chicago, IL: Section 2, page 1 .

Holzman, H. R. (1996). "Criminological Research in Public Housing: Toward a Better Understanding of People, Places and Spaces." Crime and Deliquency 42(3): 361-378.

Ingersoll, G. M., J. P. Scamman, et al. (1989). "Geographic Mobility and Student Achievement in an Urban Setting." Educational Evaluation and Policy Analysis 11: 143-149.

Jackson, B. and M. M. Garza (1999). CHA High-Rise Loses Heat as Pipes Burst. Chicago Tribune. Chicago, IL: Section 2, Page 3.

Jargowsky, P. A. (1997). Poverty and Place. New York, Russell Sage Foundation.

Jencks, C. and S. E. Mayer (1990). The Social Consequences of Growing Up in a Poor Neighborhood. Inner-City Poverty in the United States. L. E. Lynn and M. G. H. McGeary. Washington, DC, National Academy Press: 111-186.

Katz, L. F., Kling, J. and Liebman, J. (2001). "Moving to Opportunity in Boston: Early Results of a Randomized Mobility Experiment." Quarterly Journal of Economics 116(2): 607-654. 
Kaufman, J. E. and J. E. Rosenbaum (1992). "The Education and Employment of Low-Income Black Youth in White Suburbs." Educational Evaluation and Policy Analysis 14(3): 229-240.

Kerbow, D. (1996). "Patterns of Urban School Mobility and Local School Reform.” Journal of Education for Students Placed at Risk 1(2): 147-169.

Kotlowitz, A. (1991). There Are No Children Here: The Story of Two Boys Growing Up in the Other American. New York, Doubleday.

Leventhal, T. and B.-G. Jeanne (2000). Moving to Opportunity: What About the Kids? New York City, Teachers College, Columbia University.

Ludwig, J., Hirschfield, P. and Greg J. Duncan, et al. (2001). “Urban Poverty and Juvenile Crime: Evidence from a Randomized Housing-Mobility Experiment." Quarterly Journal of Economics 116(2): 665-679.

Ludwig, J., H. F. Ladd, et al. (2000). The Effects of Urban Poverty on Educational Outcomes: Evidence from a Randomized Experiment. Brookings-Wharton Conference on Urban Affairs, Washington, DC.

Massey, D. S. and N. A. Denton (1993). American Apartheid: Segregation and the Making of the Underclass. Cambridge, MA, Harvard University Press.

Means, C. o. W. a. (1998). 1998 Green Book. Washington, DC, U.S. House of Representatives.

Newman, O. (1972). Defensible Space: Crime Prevention Through Urban Design. New York, Macmillan.

Newman, O. and K. A. Franck (1980). Factors Influencing Crime and Instability in Urban Housing Developments. Washington, D.C., National Institute of Justice.

Newman, S. (1997). "". . . and a suitable living environment": The Failure of Housing Programs to Deliver on Neighborhood Quality." Housing Policy Debate 8(4).

Newman, S. and J. Harkness (1999). Assisted Housing and the Educational Attainment of Children. Baltimore, Institute for Policy Studies, Johns Hopkins University.

Newman, S., J. Harkness, et al. (1999). Neighborhood Poverty, Assisted Housing and the Educational Attainment of Children. Baltimore, MD, Johns Hopkins University Institute for Policy Studies.

Nickerson, M. (1992). Sniper Kills Cabrini Kid Steps From School. Chicago Tribune. Chicago, IL: 1 .

Ong, P. (1998). "Subsidized Housing and Work among Welfare Recipients." Housing Policy Debate 9(4): 775-794. 
Oreopoulos, Philip (2001). The Long-Run Consequences of Living in a Poor Neighborhood. Working paper. Unpublished manuscript, University of Toronto.

Popkin, S. J. and M. K. Cunningham (1999). CHAC Section 8 Program: Barriers to Successful Leasing Up. Washington, D.C., The Urban Institute.

Popkin, S. J. and M. K. Cunningham (2000). Searching for Rental Housing with Section 8 in the Chicago Region. Washington, D.C., The Urban Institute.

Popkin, S. J., Harris, L.E. and M. K. Cunningham (2001). Families in Transition: A Qualitative Analysis of the MTO Experience." Final Report submitted to the U.S. Department of Housing and Urban Development, Office of Policy Development and Research.

Reingold, David A., Ryzin, Gregg G. Van, and Michelle Ronda (2001). "Does Urban Public Housing Dimish the Social Capital and Labor Force Activity of Its Tenants?" Journal of Policy Analysis and Management 20(3): 485-504.

Rivkin, Steven G., Eric A. Hanushek and John Kain (2001). "Teachers, Schools and Academic Achievement." Working Paper, April 2001.

Rockoff, Jonah E. (2002). "The Impact of Teachers on Elementary Achievement: New Estimates from Longitudinal Micro-Data." Working Paper, Harvard University.

Roncek, D. W., R. Bell, et al. (1981). "Housing Projects and Crime: Testing a Proximity Hypothesis." Social Problems 29: 151-166.

Rosenbaum, E. and L. E. Harris (2000). "Residential Mobility and Opportunities: Early Impacts of the Moving to Opportunity Demonstration Program in Chicago." .

Rosenbaum, J. E. (1995). "Changing the Geography of Opportunity by Expanding Residential Choice: Lessons from the Gautreaux Program.” Housing Policy Debate 6: 231-269.

Russ, G. (2000). Chief of Operations, Chicago Housing Authority.

Struyk, R. J. and J. M. Bendick, Eds. (1981). Housing Vouchers for the Poor: Lessons from a National Experiment. Washington, D.C., The Urban Institute Press.

Turner, M. A. (1998). "Moving Out of Poverty: Expanding Mobility and Choice through TenantBased Housing Assistance.” Housing Policy Debate 9(2): 373-394.

Turner, M. A., S. Popkin, et al. (1998). Section 8 Mobility and Neighborhood Health. Washington, DC, Urban Institute Press. 
Varady, D. P. and C. C. Walker (2000). "Vouchering Out Distressed Subsidized Developments: Does Moving Lead to Improvements in Housing and Neighborhood Conditions?" Housing Policy Debate 11(1): 115-162.

Zagel, J. B. (1995). Amended Consent Decree: Henry Horner Mothers Guild et. al. vs. Chicago Housing Authority et. al. Chicago, IL, United States District Court for the Northern District of Illinois Eastern Division. 
Appendix A: Definition of Variables

\begin{tabular}{|c|c|c|}
\hline Variables & $\begin{array}{c}\text { Data } \\
\text { Source }\end{array}$ & Definition \\
\hline \multicolumn{3}{|l|}{ Demographics } \\
\hline $\begin{array}{l}\text { Student } \\
\text { Demographics (Race, } \\
\text { Gender, Birthdate, } \\
\text { Household } \\
\text { Composition, Free or } \\
\text { Reduced Lunch, } \\
\text { Special Education) } \\
\end{array}$ & ChiPS & $\begin{array}{l}\text { Taken directly from student records. Household } \\
\text { composition is drawn from information on the student's } \\
\text { guardian, which varies by semester. I take semester prior } \\
\text { to the notification date. }\end{array}$ \\
\hline \multicolumn{3}{|l|}{$\begin{array}{l}\text { Public Housing } \\
\text { Status }\end{array}$} \\
\hline $\begin{array}{l}\text { Residence in Public } \\
\text { Housing and/or High- } \\
\text { Rise Public Housing }\end{array}$ & CHA & $\begin{array}{l}\text { High rises are defined as buildings with at least } 75 \text { units } \\
\text { (most often over } 100 \text { units). Annual (high rise) public } \\
\text { housing and high-rise residence are defined as the } \\
\text { fraction of the year the student lived in (high rise) public } \\
\text { housing ( } 0, .5 \text { or } 1 \text {, corresponding to } 0,1 \text { or } 2 \text { semesters } \\
\text { in that academic year). }\end{array}$ \\
\hline \multicolumn{3}{|l|}{$\begin{array}{l}\text { Neighborhood and } \\
\text { School } \\
\text { Characteristics }\end{array}$} \\
\hline $\begin{array}{l}\text { Neighborhood } \\
\text { Poverty Rate }\end{array}$ & Census & $\begin{array}{l}\text { From the } 1990 \text { Census data. Based on the census tract in } \\
\text { which the student was living. The annual poverty rate is } \\
\text { the mean of Fall and Spring rates. }\end{array}$ \\
\hline $\begin{array}{l}\% \text { school peers } \\
\text { meeting national } \\
\text { norms in math }\end{array}$ & ChiPS & From school level records. \\
\hline $\begin{array}{l}\text { Miles from Original } \\
\text { Residence }\end{array}$ & Census & $\begin{array}{l}\text { Indicates the distance between the residential census tract } \\
\text { at the time of the closure announcement and the current } \\
\text { census tract in any year. Distances are measured between } \\
\text { the centroids of the tracts. }\end{array}$ \\
\hline \multicolumn{3}{|r|}{ ( } \\
\hline $\begin{array}{l}\text { Residential \& School } \\
\text { Mobility }\end{array}$ & ChiPS & $\begin{array}{l}\text { Residential mobility is based on changes in home address } \\
\text { and school mobility is based on changes in current } \\
\text { school, both of which are contained in the student } \\
\text { records. Because data is only available once per } \\
\text { semester, the estimates of residential and school mobility } \\
\text { may be understated. For example, if a student changed } \\
\text { residences or school after September but had returned to } \\
\text { her original home address or school by the following } \\
\text { May, then moves will not be recorded. Since I only have } \\
\text { data on three time points during the calendar year } \\
\text { (September, May and the following September), the } \\
\text { maximum number of moves is two. }\end{array}$ \\
\hline
\end{tabular}




\begin{tabular}{|l|l|l|}
\hline $\begin{array}{l}\text { Educational } \\
\text { Outcomes }\end{array}$ & ChiPS & $\begin{array}{l}\text { A student is considered old for grade if Age (in } \\
\text { September) }>\text { Grade }+6.5 \text {. Students in non-graded } \\
\text { classrooms received a missing for this variable. }\end{array}$ \\
\hline Old for Grade & ChiPS & $\begin{array}{l}\text { From student test files. These variables are measured in } \\
\text { terms of national percentile ranks. }\end{array}$ \\
\hline $\begin{array}{l}\text { Math \& Reading } \\
\text { Scores }\end{array}$ & ChiPS & $\begin{array}{l}\text { From high school transcript files. GPA is a measure of } \\
\text { cumulative high school GPA measured in May of the } \\
\text { academic year (i.e., GPA in 1994 is the GPA from May } \\
\text { 1994, referring to the 1993-1994 academic year). } \\
\text { Absences refer to the average number of days missed per } \\
\text { course in that academic year. Credits refer to the total } \\
\text { number of credits earned in that academic year. }\end{array}$ \\
\hline $\begin{array}{l}\text { Left the district, } \\
\text { dropped out and } \\
\text { enrollment status. }\end{array}$ & ChiPS & $\begin{array}{l}\text { Student records provide reasons why the student has left } \\
\text { the ChiPS, including transfer to a private school } \\
\text { (code=32), moved to another district (code=33), } \\
\text { graduated (code=45). Student records also provide } \\
\text { separate information regarding whether a student is } \\
\text { actively enrolled in any one semester. In some cases, a } \\
\text { student who has not left the ChiPS may not be enrolled } \\
\text { due to illness, excessive absence, etc. }\end{array}$ \\
\hline
\end{tabular}




\section{Appendix B: Determination of Notification and Closure Dates}

Data on building closures and demolitions was gathered from a variety of sources. The CHA provided information on which buildings had been demolished and the date of demolition. However, during this period, a number of other buildings were vacated in preparation for future demolition. For this analysis, it is crucial to not only identify these buildings, but also determine the approximate date tenants were notified of the closure. Consider, for example, the impact of building closures on school mobility. Suppose tenants in a particular development were notified in October 1995 that their building was to be closed in January 1996. Because families moved out between October and January, it is likely that the affected children changed schools at this time as well. If we measure school mobility after January 1996, we will likely understate the impact of the closure. Similar problems arise if we pick an arbitrary date prior to the closure. Suppose we choose to start tracking student mobility one year prior to the official closure date. Because public housing residents are quite mobile, it is likely that at least some of the students in our sample would have changed schools during that year even before the closure was announced. Moreover, children in buildings that were not slated for closure might be just as likely to move as children in the soon to be closed buildings. Therefore, if we begin tracking students significantly in advance of the closure announcement, we will not be able to attribute the mobility to the closure and, more importantly, we may see little difference in student performance by building.

CHA policy requires tenants be notified at least 120 days prior to a building closure. However, this is often a poor approximation for the time at which tenants were aware of building closures. On one hand, a number of buildings were vacated and closed in shorter than 120 days due to emergency maintenance problems, particularly in the winter months. In these cases, tenants were sometimes given as little as a week notice prior to closure. On the other hand, there 
were instances in which redevelopment had been planned for several years and tenants knew of the impending closures well in advance of the official notification.

In order to identify which buildings had been vacated and to determine the approximate date that residents were notified, I examined the trends in the monthly occupancy rates by building since 1990 provided by the CHA. Because many public housing buildings in Chicago experienced slow declines in occupancy over this decade, I rely on sharp declines in building occupancy followed by vacancy to identify the initial notification date. Figure B1 illustrates occupancy rates and closure announcements for several buildings. Residents of building \#9 in the Henry Horner Homes were notified in June 1996; the occupancy rate in the building dropped from forty percent to one percent the next month. In other cases, such as Cabrini-Green \#104 and Washington Park \#44, a large fraction of residents left immediately after the announcement (i.e., June 1996 in these cases), but the remaining tenants left over a period of several years. Finally, in many buildings the occupancy rate had been declining for several years prior to the closure, largely because the CHA had stopped assigning new tenants to the building due to maintenance problems. This was the case in Robert Taylor \#20, where occupancy steadily declined from June 1996 until October 1999 when the building was vacated and closed over a two-month period in anticipation of winter heating problems. I conduct a similar analysis using the annual public school enrollment by building.

Finally, I supplement these analyses with information from interviews with CHA officials, housing advocates and the presidents of the Local Advisory Councils (LACs) in all 13 of the developments that experienced some building closures during this period. The LAC presidents were particularly helpful in determining the sequences of events in the developments and determining when residents became aware of the closures. 


\section{Appendix C: Sample Construction}

Recall that students are categorized according to the building in which they were living in the semester prior to the initial closure notification. These categorizations are referred to as base groups. Note that students may be in more than one base group if they lived in several different developments that experienced closures during this period. For example, if a family lived in the Robert Taylor Homes in May 1995 and later moved to the Washington Park development prior to May 1997 when a set of building closures were announced in that development, the family will be included in both the Taylor '95 and Washington Park '97 base groups. Similarly, there may be more than one base group per development. For example, closure announcements in the Taylor Homes took place in 1995, 1997 and 1998, each year for a different set of buildings. Therefore, there are four separate Taylor base groups.

Because certain developments experienced a series of building closures at different times, $\gamma_{j}$ is actually a vector of development*year effects. In practice, I handle this by expanding the data so that a student's data appears once for each base group (i..e, a student who belongs to four base groups will appear four times in the data set) and then correcting the standard errors to account for this. Just as it is possible for students to be in multiple base groups, it is also possible for students to be in multiple demolition groups. For example, a student might be living in a building within Robert Taylor in 1995 when its closure is announced and then move to a building in ABLA that is closed in 1998. Fortunately, there are extremely few students with multiple demolition groups. For these students, I simply consider the first demolition group, thus assuming that the initial disruption is the treatment of interest. 
Table 1: Summary Statistics on Chicago Public School (CPS) Students in Spring 1995

Students who Lived in

Public Housing

\begin{tabular}{|c|c|c|c|}
\hline \multirow[b]{2}{*}{ Dependent Variable } & \multirow[b]{2}{*}{$\begin{array}{l}\text { All CPS } \\
\text { Students }\end{array}$} & \\
\hline & & $\begin{array}{c}\text { All } \\
\text { Developments }\end{array}$ & $\begin{array}{l}\text { Developments } \\
\text { with Closures }\end{array}$ \\
\hline \multirow{2}{*}{ Male } & 0.51 & 0.50 & 0.50 \\
\hline & $(0.50)$ & $(0.50)$ & $(0.50)$ \\
\hline \multirow{2}{*}{ Black } & 0.55 & 0.96 & 1.00 \\
\hline & $(0.50)$ & $(0.20)$ & $(0.06)$ \\
\hline \multirow{2}{*}{ Hispanic } & 0.30 & 0.01 & 0.00 \\
\hline & $(0.46)$ & $(.11)$ & $(0.05)$ \\
\hline \multirow{2}{*}{ Age } & 11.3 & 10.4 & 10.8 \\
\hline & $(3.9)$ & $(3.9)$ & $(3.9)$ \\
\hline \multirow{2}{*}{ Living with at least one parent } & 0.863 & 0.911 & 0.910 \\
\hline & $(0.344)$ & $(0.285)$ & $(0.286)$ \\
\hline \multirow{2}{*}{ Living in foster care } & 0.037 & 0.047 & 0.050 \\
\hline & $(0.190)$ & $(0.211)$ & $(0.217)$ \\
\hline \multirow{2}{*}{ Old for grade } & 0.07 & 0.10 & 0.10 \\
\hline & $(.25)$ & $(.30)$ & $(.31)$ \\
\hline \multirow{2}{*}{ Free lunch } & 0.719 & 0.907 & 0.913 \\
\hline & $(0.450)$ & $(0.290)$ & $(0.282)$ \\
\hline \multirow{2}{*}{ Reduced price lunch } & 0.065 & 0.008 & 0.005 \\
\hline & $(0.246)$ & $(0.089)$ & $(0.072)$ \\
\hline \multirow{2}{*}{ Special Education } & 0.118 & 0.135 & 0.133 \\
\hline & $(0.322)$ & $(0.342)$ & $(0.339)$ \\
\hline \multirow{2}{*}{ Math Score (percentile rank) } & 35.2 & 23.5 & 22.3 \\
\hline & $(27.4)$ & $(22.5)$ & $(22.1)$ \\
\hline \multirow{2}{*}{ Reading Score (percentile rank) } & 34.4 & 23.8 & 22.2 \\
\hline & $(24.3)$ & $(19.1)$ & $(18.4)$ \\
\hline \multirow{2}{*}{ GPA } & 1.88 & 1.42 & 1.36 \\
\hline & $(1.02)$ & $(0.93)$ & $(0.94)$ \\
\hline \multirow{2}{*}{ Absences (per course) } & 18.5 & 28.8 & 31.4 \\
\hline & $(17.5)$ & $(20.7)$ & $(21.2)$ \\
\hline \multirow{2}{*}{ Course Credits } & 22.8 & 22.5 & 22.5 \\
\hline & $(2.8)$ & $(3.3)$ & $(3.3)$ \\
\hline \multirow{2}{*}{ Census Tract Poverty Rate } & 0.27 & 0.72 & 0.82 \\
\hline & $(0.21)$ & $(0.21)$ & $(0.11)$ \\
\hline \multirow{2}{*}{$\%$ school peers meeting national norms in math } & 0.28 & 0.17 & 0.16 \\
\hline & $(0.17)$ & $(0.11)$ & $(0.11)$ \\
\hline Number of Observations & 416,104 & 28,996 & 18,484 \\
\hline
\end{tabular}

Notes: Standard deviations are presented in parentheses below the group means. 
Table 2: Differences Between Demolition and Control Students Prior to the Closure Announcement

\begin{tabular}{|c|c|c|}
\hline Dependent Variable & $\begin{array}{c}\text { Control Mean } \\
\text { (s.d.) }\end{array}$ & $\begin{array}{c}\text { Difference: } \\
\text { Demo - Controls } \\
\text { (s.e.) }\end{array}$ \\
\hline Male & $\begin{array}{c}0.508 \\
(0.500)\end{array}$ & $\begin{array}{l}-0.014 \\
(0.012)\end{array}$ \\
\hline Living with at least one parent & $\begin{array}{c}0.920 \\
(0.272)\end{array}$ & $\begin{array}{l}-0.003 \\
(0.011)\end{array}$ \\
\hline Living in foster care & $\begin{array}{c}0.046 \\
(0.210)\end{array}$ & $\begin{array}{c}0.004 \\
(0.008)\end{array}$ \\
\hline In Special Education & $\begin{array}{c}0.114 \\
(0.318)\end{array}$ & $\begin{array}{l}-0.003 \\
(0.009)\end{array}$ \\
\hline Free Lunch & $\begin{array}{c}0.883 \\
(0.322)\end{array}$ & $\begin{array}{l}-0.009 \\
(0.009)\end{array}$ \\
\hline Age & $\begin{array}{l}10.34 \\
(4.02)\end{array}$ & $\begin{array}{l}-0.323 * * \\
(0.143)\end{array}$ \\
\hline Old for Grade & $\begin{array}{c}0.197 \\
(0.410)\end{array}$ & $\begin{array}{c}0.013 \\
(0.012)\end{array}$ \\
\hline Math Score (percentile rank) & $\begin{array}{c}25.1 \\
(24.2)\end{array}$ & $\begin{array}{l}-0.73 \\
(1.53)\end{array}$ \\
\hline Reading Score (percentile rank) & $\begin{array}{l}22.8 \\
(20.4)\end{array}$ & $\begin{array}{l}-0.40 \\
(1.07)\end{array}$ \\
\hline Math Gain in Prior Year & $\begin{array}{c}0.02 \\
(18.60)\end{array}$ & $\begin{array}{c}0.13 \\
(0.98)\end{array}$ \\
\hline Reading Gain in Prior Year & $\begin{array}{c}0.02 \\
(17.83)\end{array}$ & $\begin{array}{c}0.14 \\
(0.80)\end{array}$ \\
\hline GPA & $\begin{array}{c}1.458 \\
(0.908)\end{array}$ & $\begin{array}{c}0.056 \\
(0.044)\end{array}$ \\
\hline Absences (per course) & $\begin{array}{c}23.7 \\
(16.8)\end{array}$ & $\begin{array}{l}-0.458 \\
(0.690)\end{array}$ \\
\hline Credits & $\begin{array}{l}23.0 \\
(3.5)\end{array}$ & $\begin{array}{c}0.105 \\
(0.217)\end{array}$ \\
\hline Moved in Past Year & $\begin{array}{c}0.114 \\
(0.313)\end{array}$ & $\begin{array}{l}-0.016 \\
(0.016)\end{array}$ \\
\hline Changed Schools in Past Year & $\begin{array}{c}0.169 \\
(0.374)\end{array}$ & $\begin{array}{c}0.007 \\
(0.011)\end{array}$ \\
\hline Census Tract Poverty Rate & $\begin{array}{c}0.844 \\
(0.100)\end{array}$ & $\begin{array}{c}0.004 \\
(0.012)\end{array}$ \\
\hline Percent school peers met norms in math & $\begin{array}{c}0.181 \\
(0.104)\end{array}$ & $\begin{array}{l}-0.003 \\
(0.014)\end{array}$ \\
\hline
\end{tabular}

Notes: The total number of observations is 10,556, although the number of observations varies somewhat across specification because certain outcomes are only available for elementary or secondary students. The first column shows the control group means with the standard deviations in parentheses in the year prior to the closure announcement. Column 2 shows the difference between treatments and controls in the year prior to the closure announcement. The differences shown in column 2 are estimated from a regression model that includes fixed effects for housing development and year and, for achievement measures, fixed effects for age. The number of observations varies across the dependent variables because certain outcomes are only available for elementary or secondary students. In column 2, EickerWhite robust standard errors clustered by public housing building are shown in parenthesis. 
Table 3: The Impact of Public Housing Closures Three Years After Initial Notification

\begin{tabular}{|c|c|c|c|c|}
\hline Dependent Variable & $\begin{array}{c}\text { Control } \\
\text { Mean } \\
(1)\end{array}$ & $\begin{array}{c}\text { Diff: } \\
\text { Demo - Cont } \\
\text { (no controls) } \\
(2)\end{array}$ & $\begin{array}{c}\text { Diff: } \\
\text { Demo - Cont } \\
\text { (controls) } \\
(3)\end{array}$ & $\begin{array}{c}\text { Diff: } \\
\text { Demo - Cont } \\
\text { (controls) } \\
(4)\end{array}$ \\
\hline \multicolumn{5}{|l|}{ Sample Attrition } \\
\hline Left the ChiPS (i.e., transferred to a private & 0.061 & 0.000 & 0.000 & 0.000 \\
\hline school or moved out of the district) & $(0.239)$ & $(0.002)$ & $(0.006)$ & $(0.006)$ \\
\hline Enrolled in school & 0.899 & -0.011 & -0.006 & -0.007 \\
\hline (ages 3-13) & $(0.277)$ & $(0.007)$ & $(0.007)$ & $(0.007)$ \\
\hline Missing Transcript Outcomes & 0.823 & 0.000 & 0.000 & 0.000 \\
\hline$($ ages $3-13)$ & $(0.382)$ & $(0.006)$ & $(0.006)$ & $(0.006)$ \\
\hline Missing Test Score Outcomes & 0.335 & 0.004 & 0.000 & 0.000 \\
\hline (ages 3-13) & $(0.472)$ & $(0.009)$ & $(0.009)$ & $(0.009)$ \\
\hline \multicolumn{5}{|l|}{ Educational Outcomes } \\
\hline $\begin{array}{l}\text { Dropped out } \\
\text { (ages } 14+\text { ) }\end{array}$ & $\begin{array}{c}0.538 \\
(0.499)\end{array}$ & $\begin{array}{r}0.048^{*} \\
(0.025)\end{array}$ & $\begin{array}{l}0.043 * * \\
(0.022)\end{array}$ & $\begin{array}{l}0.044 * * \\
(0.021)\end{array}$ \\
\hline Math Score (percentile rank) & $\begin{array}{c}31.6 \\
(24.8)\end{array}$ & $\begin{array}{l}-0.474 \\
(0.858)\end{array}$ & $\begin{array}{l}-0.401 \\
(0.835)\end{array}$ & $\begin{array}{l}0.200 \\
(0.762)\end{array}$ \\
\hline \multirow{2}{*}{ Reading Score (percentile rank) } & 27.6 & -0.196 & -0.159 & 0.099 \\
\hline & $(21.0)$ & $(0.246)$ & $(0.730)$ & $(0.680)$ \\
\hline \multirow{2}{*}{ Old for Grade } & 0.330 & -0.005 & -0.006 & -0.005 \\
\hline & $(0.470)$ & $(0.014)$ & $(0.012)$ & $(0.012)$ \\
\hline \multirow{2}{*}{ Absences (per course) } & 14.8 & 0.38 & 0.41 & 0.57 \\
\hline & $(11.4)$ & $(0.96)$ & $(0.97)$ & $(0.98)$ \\
\hline \multirow{2}{*}{ Credits } & 25.4 & 0.49 & 0.42 & 0.35 \\
\hline & $(4.7)$ & $(0.28)$ & $(0.28)$ & $(0.28)$ \\
\hline \multirow{2}{*}{ GPA } & 1.55 & 0.017 & 0.010 & -0.017 \\
\hline & $(0.93)$ & $(0.069)$ & $(0.067)$ & $(0.064)$ \\
\hline \multicolumn{5}{|l|}{ Relocation Outcomes } \\
\hline \multirow{2}{*}{ Living in Public Housing } & 0.615 & $-0.205 * *$ & $-0.204 * *$ & $-0.200 * *$ \\
\hline & $(0.449)$ & $(0.012)$ & $(0.012)$ & $(0.012)$ \\
\hline \multirow{2}{*}{ Years in public housing } & 2.19 & $-0.596 * *$ & $-0.594 * *$ & $-0.576 * *$ \\
\hline & $(1.07)$ & $(0.032)$ & $(0.032)$ & $(0.032)$ \\
\hline \multirow{2}{*}{ Miles from original residence } & 1.45 & $1.29 * *$ & $1.29 * *$ & $1.26^{* *}$ \\
\hline & $(2.56)$ & $(0.08)$ & $(0.08)$ & $(0.08)$ \\
\hline \multirow{2}{*}{ Census Tract Poverty Rate } & 0.676 & $-0.147 * *$ & $-0.146^{* *}$ & $-0.143 * *$ \\
\hline & $(0.269)$ & $(0.008)$ & $(0.008)$ & $(0.008)$ \\
\hline \multirow{2}{*}{ Changed Schools Since Notification } & 0.576 & $0.172 * *$ & $0.172 * *$ & $0.170 * *$ \\
\hline & $(0.494)$ & $(0.013)$ & $(0.013)$ & $(0.012)$ \\
\hline \multirow{2}{*}{ \# of School Moves ${ }^{\mathrm{a}}$} & 1.45 & 0.01 & 0.01 & 0.01 \\
\hline & $(0.69)$ & $(0.03)$ & $(0.03)$ & $(0.02)$ \\
\hline \multirow{2}{*}{ Percent school peers met norms in math } & 0.274 & 0.001 & 0.002 & -0.002 \\
\hline & $(0.112)$ & $(0.003)$ & $(0.003)$ & $(0.003)$ \\
\hline Controls for student demographics & -- & No & Yes & Yes \\
\hline Controls for prior achievement & -- & No & No & Yes \\
\hline
\end{tabular}

Notes: The sample sizes for the attrition and dropout estimates are 10,556 for the full sample, 7,635 for the younger children (age 3-13) and 2,251 for the older children (age 14-21). The education and relocation estimates are based on the sample of younger children still enrolled three years after the initial notification $(n=6,681)$, but the number of observations varies because of missing data and because some 
outcomes are only available for elementary or secondary students. Eicker-White robust standard errors that account for correlation within students are shown in parentheses. The estimates in column 2 include fixed effects for building, announcement year and grade at announcement. The estimates in column 3 include the following additional controls: age, gender, living with at least one parent, living in foster care, special education, free lunch and old for grade. The estimates in column 4 include all of the controls from columns 2 and 3 as well as controls for student achievement in the year prior to the closure notification, including math score, reading score, GPA, credits and absences (imputed values and indicators for missing data are included for students without prior achievement measures). ${ }^{\mathrm{a}}$ Conditional on having changed schools. $*=$ significant at the $10 \%$ level, $* *=$ significant at the $5 \%$ level. 
Table 4: The Effects of Public Housing Closures Over Time

\begin{tabular}{|c|c|c|c|c|c|}
\hline & \multicolumn{5}{|c|}{ Difference: Demo - Cont } \\
\hline & Year 1 & Year 2 & Year 3 & Year 4 & Year 5 \\
\hline \multicolumn{6}{|l|}{ Sample Attrition $(n=7,483)$} \\
\hline Left the ChiPS (i.e., transferred to & 0.002 & -0.002 & 0.001 & 0.005 & 0.001 \\
\hline private, or moved out of the district) & $(0.005)$ & $(0.006)$ & $(0.007)$ & $(0.008)$ & $(0.009)$ \\
\hline Enrolled in School (ages 3-13; & -0.001 & -0.002 & -0.007 & -0.006 & -0.005 \\
\hline $\mathrm{n}=5,603)$ & $(0.006)$ & $(0.008)$ & $(0.009)$ & $(0.011)$ & $(0.011)$ \\
\hline Missing Test Score Outcomes & 0.031 & 0.030 & 0.000 & 0.016 & 0.004 \\
\hline$($ ages $3-13 ; n=5,603)$ & $(0.011)$ & $(0.012)$ & $(0.011)$ & $(0.012)$ & $(0.011)$ \\
\hline \multicolumn{6}{|l|}{ Educational Outcomes $(n=3,889)$} \\
\hline Dropped Out (age 14+, n=1,678) & $\begin{array}{c}0.036 \\
(0.024)\end{array}$ & $\begin{array}{l}0.047^{*} \\
(0.027)\end{array}$ & $\begin{array}{r}0.067 * * \\
(0.027)\end{array}$ & $\begin{array}{r}0.085 * * \\
(0.027)\end{array}$ & $\begin{array}{r}0.074 * * \\
(0.026)\end{array}$ \\
\hline \multirow{2}{*}{ Old for Grade } & -0.002 & 0.003 & 0.000 & 0.005 & 0.005 \\
\hline & $(0.010)$ & $(0.016)$ & $(0.018)$ & $(0.019)$ & $(0.019)$ \\
\hline \multirow{2}{*}{ Math Score (percentile rank) } & -0.041 & -0.326 & -0.079 & 0.364 & 0.489 \\
\hline & $(1.110)$ & $(1.142)$ & $(1.104)$ & $(1.131)$ & $(1.154)$ \\
\hline \multicolumn{6}{|l|}{ Relocation Outcomes $(n=3,889)$} \\
\hline \multirow{2}{*}{ Living in Public Housing } & $-0.100 * *$ & $-0.185 * *$ & $-0.174 * *$ & $-0.165 * *$ & $-0.111 * *$ \\
\hline & $(0.016)$ & $(0.020)$ & $(0.020)$ & $(0.020)$ & $(0.019)$ \\
\hline \multirow{2}{*}{ Census Tract Poverty Rate } & $-0.058 * *$ & $-0.106 * *$ & $-0.107 * *$ & $-0.109 * *$ & $-0.081 * *$ \\
\hline & $(0.009)$ & $(0.010)$ & $(0.011)$ & $(0.011)$ & $(0.011)$ \\
\hline \multirow{2}{*}{ Changed Schools Since Notification } & $0.157 * *$ & $0.196 * *$ & $0.192 * *$ & $0.179 * *$ & $0.123 * *$ \\
\hline & $(0.020)$ & $(0.020)$ & $(0.020)$ & $(0.018)$ & $(0.016)$ \\
\hline \multirow{2}{*}{$\begin{array}{l}\text { Percent school peers met norms in } \\
\text { math }\end{array}$} & -0.001 & 0.006 & 0.001 & 0.004 & 0.003 \\
\hline & $(0.003)$ & $(0.004)$ & $(0.004)$ & $(0.004)$ & $(0.004)$ \\
\hline Controls for student demographics & Yes & Yes & Yes & Yes & Yes \\
\hline Controls for prior achievement & Yes & Yes & Yes & Yes & Yes \\
\hline
\end{tabular}

Notes: The sample for this analysis includes students in public housing developments that experienced closures before 1997. The top panel includes all students in the relevant buildings immediately prior to closure notification $(\mathrm{n}=7,483)$. The achievement and relocation estimates in the bottom two panels include the sub-sample of younger children (3-13) who were still enrolled five years after notification $(n=3,889)$. The difference in sample size is due to students who graduated, dropped out or left the system. The number of observations varies across the dependent variables because certain outcomes are only available for elementary or secondary students. Eicker-White robust standard errors that account for correlation within students are shown in parentheses. The controls included are the same as those in column 4 of Table $3 . *=$ significant at the $10 \%$ level, $* *=$ significant at the $5 \%$ level. 


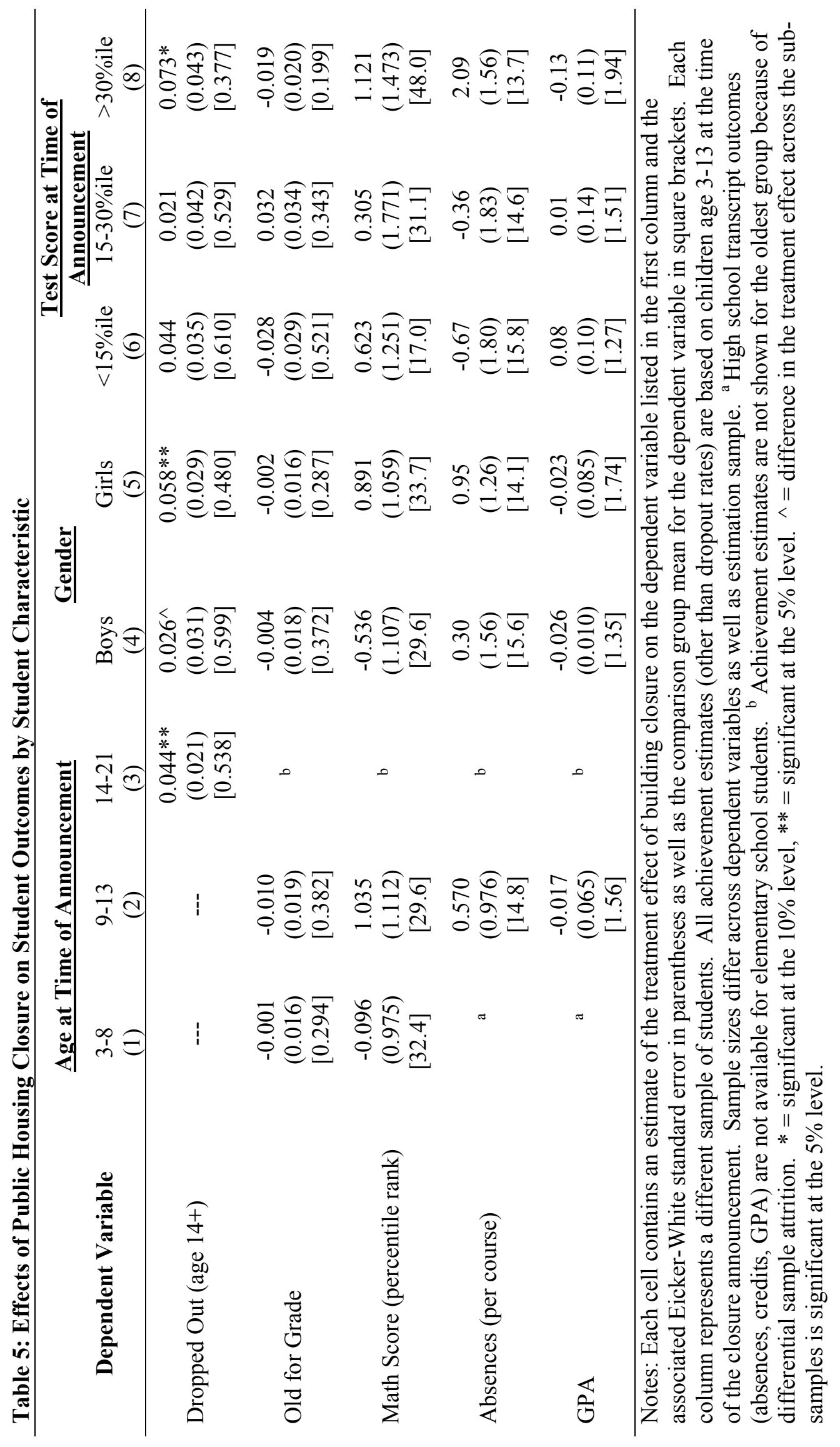



Table 6: The Effect of Building Closing on Student Outcomes by Closure Characteristic

\begin{tabular}{|c|c|c|c|c|}
\hline & $\begin{array}{c}\text { Earlier } \\
\text { Closures } \\
\text { (pre-1996) } \\
(1) \\
\end{array}$ & $\begin{array}{c}\text { Later } \\
\text { Closures } \\
\text { (post-1996) } \\
(2) \\
\end{array}$ & $\begin{array}{c}\text { Unplanned } \\
\text { Closures } \\
(3) \\
\end{array}$ & $\begin{array}{c}\text { Planned } \\
\text { Closures } \\
(4)\end{array}$ \\
\hline \multicolumn{5}{|l|}{ Sample Attrition } \\
\hline $\begin{array}{l}\text { Left the ChiPS (i.e., transferred to private, or } \\
\text { moved out of the district) }\end{array}$ & $\begin{array}{c}0.001 \\
(0.007)\end{array}$ & $\begin{array}{c}0.001 \\
(0.010)\end{array}$ & $\begin{array}{c}0.002 \\
(0.008)\end{array}$ & $\begin{array}{l}-0.002 \\
(0.008)\end{array}$ \\
\hline Enrolled in School (ages 3-13) & $\begin{array}{l}-0.007 \\
(0.009)\end{array}$ & $\begin{array}{l}-0.008 \\
(0.010)\end{array}$ & $\begin{array}{c}0.000 \\
(0.009)\end{array}$ & $\begin{array}{c}-0.017^{*} \\
(0.10)\end{array}$ \\
\hline Missing Test Score (ages 3-13) & $\begin{array}{c}0.000 \\
(0.011)\end{array}$ & $\begin{array}{c}0.006 \\
(0.013) \\
\end{array}$ & $\begin{array}{c}0.010 \\
(0.011)\end{array}$ & $\begin{array}{l}-0.009 \\
(0.013)\end{array}$ \\
\hline \multicolumn{5}{|l|}{ Educational Outcomes } \\
\hline Dropped Out (ages 14+) & $\begin{array}{c}0.067 * * \\
(0.027)\end{array}$ & $\begin{array}{l}0.005^{\wedge} \\
(0.034)\end{array}$ & $\begin{array}{l}0.047^{*} \\
(0.026)\end{array}$ & $\begin{array}{c}0.051 \\
(0.032)\end{array}$ \\
\hline Math Score (percentile rank) (ages 3-13) & $\begin{array}{l}-0.442 \\
(1.036)\end{array}$ & $\begin{array}{l}1.331 \\
(1.126)\end{array}$ & $\begin{array}{l}1.601 \\
(0.977)\end{array}$ & $\begin{array}{l}-1.530 \\
(1.110)\end{array}$ \\
\hline Old for Grade (ages 3-13) & $\begin{array}{c}0.008 \\
(0.016)\end{array}$ & $\begin{array}{l}-0.014 \\
(0.018)\end{array}$ & $\begin{array}{l}-0.010 \\
(0.016)\end{array}$ & $\begin{array}{c}0.008 \\
(0.017)\end{array}$ \\
\hline Absences (per course) (ages 3-13) & $\begin{array}{l}1.056 \\
(1.426)\end{array}$ & $\begin{array}{l}-0.407 \\
(1.262)\end{array}$ & $\begin{array}{c}1.337 \\
(1.308)\end{array}$ & $\begin{array}{l}-0.164 \\
(1.402)\end{array}$ \\
\hline \multicolumn{5}{|l|}{$\underline{\text { Relocation Outcomes }}$} \\
\hline Living in Public Housing & $\begin{array}{c}-0.189 * * \\
(0.018)\end{array}$ & $\begin{array}{c}-0.293 * * \\
(0.015)\end{array}$ & $\begin{array}{c}-0.215 * * \\
(0.015)\end{array}$ & $\begin{array}{r}-0.177 * * \\
(0.179)\end{array}$ \\
\hline Miles from original residence & $\begin{array}{l}1.38^{* *} \\
(0.11)\end{array}$ & $\begin{array}{l}1.03 * * \\
(0.08)\end{array}$ & $\begin{array}{l}1.08 * * \\
(0.10)\end{array}$ & $\begin{array}{l}1.49 * * \\
(0.13)\end{array}$ \\
\hline Census Tract Poverty Rate & $\begin{array}{c}-0.108 * * \\
(0.010)\end{array}$ & $\begin{array}{c}-0.152 * * \\
(0.010)\end{array}$ & $\begin{array}{c}-0.163 * * \\
(0.010)\end{array}$ & $\begin{array}{c}-0.119 * * \\
(0.010)\end{array}$ \\
\hline Percent school peers met norms in math & $\begin{array}{c}0.003 \\
(0.003)\end{array}$ & $\begin{array}{c}0.000 \\
(0.004)\end{array}$ & $\begin{array}{l}-0.003 \\
(0.004)\end{array}$ & $\begin{array}{l}-0.001 \\
(0.004)\end{array}$ \\
\hline Number of Treatment Students & 1,774 & 1,752 & 2,014 & 1,480 \\
\hline Number of Control Students & 5,709 & 1,321 & 7,030 & 7,030 \\
\hline
\end{tabular}

Notes: Each cell contains an estimate of the treatment effect of building closure on the dependent variable listed in the first column and the associated Eicker-White standard error in parentheses. Each column provides estimates for a different sample of students. All achievement estimates (other than dropout rates) are based on children age 3-13 at the time of the closure announcement. The number of observations reflected in each cell varies across the dependent variables because certain outcomes are only available for elementary or secondary students. All models include development and year fixed effects as well as the full set of controls used to generate the estimates shown in column 4 of Table 3 . Planned closures are defined as those in which there was at least a year between notification and vacancy; in unplanned closures vacancy occurred more than a year after the notification. $*=$ significant at the $10 \%$ level, $* *=$ significant at the $5 \%$ level. ${ }^{\wedge}=$ difference in the treatment effect across sub-samples is significant at the $5 \%$ level. 
Table 7: The Relationship Between Public Housing Participation and Student Achievement

\begin{tabular}{lccc}
\hline \multicolumn{1}{c}{ Outcome Variables } & First Stage & OLS & 2SLS \\
\hline \multirow{2}{*}{ Math Score (percentile rank) } & -0.600 & 0.055 & -0.331 \\
& $(0.037)$ & $(0.281)$ & $(1.261)$ \\
Reading Score (percentile rank) & $\mathrm{F}=263.1$ & -0.236 & -0.163 \\
& -0.600 & $(0.248)$ & $(1.127)$ \\
Old for Grade & $(0.037)$ & & \\
& $\mathrm{F}=263.1$ & 0.004 & 0.008 \\
Absences (per course) & -0.597 & $(0.005)$ & $(0.020)$ \\
& $(0.032)$ & & -2.890 \\
Credits & $\mathrm{F}=351.2$ & 1.186 & $(5.018)$ \\
& -0.197 & $(0.846)$ & -1.791 \\
GPA & $(0.032)$ & & $(1.452)$ \\
& $\mathrm{F}=36.6$ & -0.065 & $(0.291)$ \\
\end{tabular}

Notes: Absences, course credits and GPA refer to high school outcomes in the third year following the closure announcement. The independent variable for public housing participation in these models is a binary indicator of whether the student was living in public housing during this academic year. The coefficient on the demolition indicator in the first stage regressions for these models is -0.197 with a standard error of 0.032 , which coincides with the 20-percentage point effect shown in Table 3. 
Figure 1: The Net Effect of Demolition on Student Outcomes

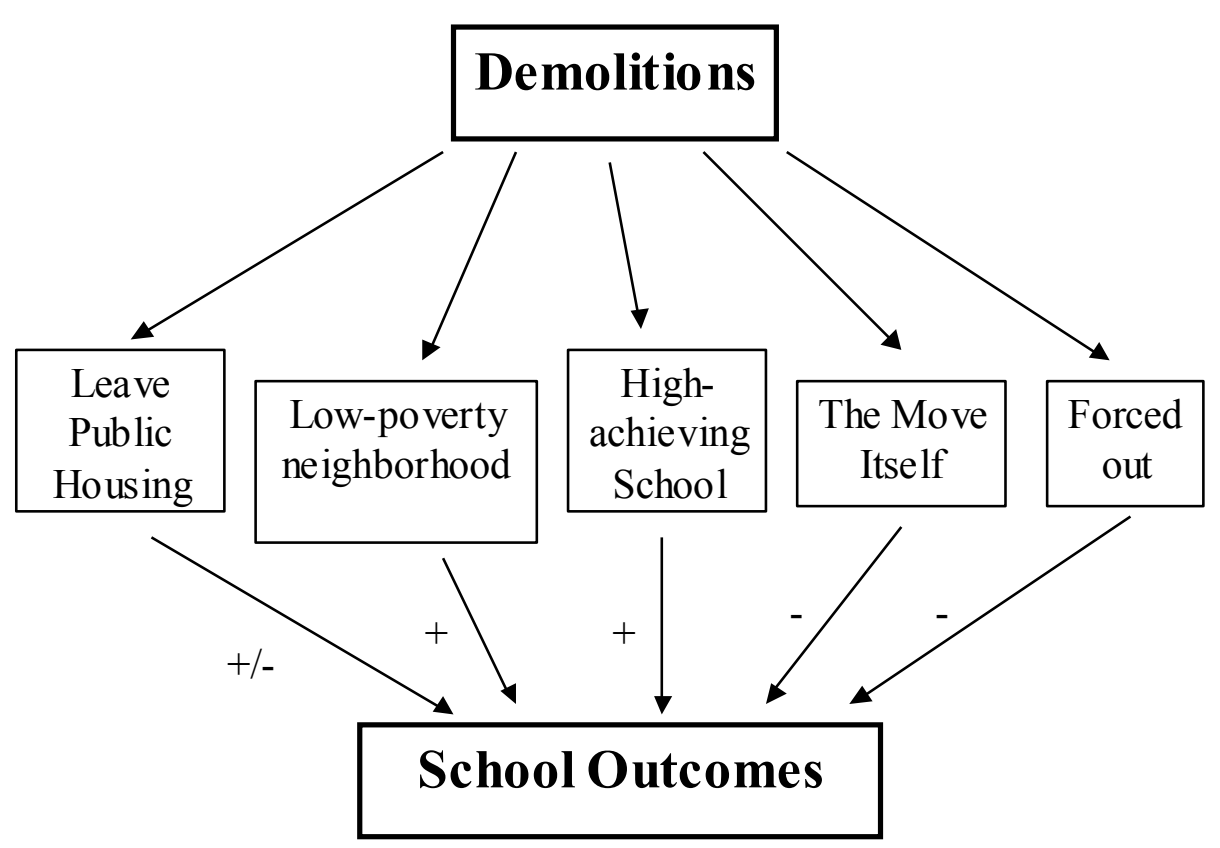


Figure 2: The Relationship Between Public Housing Closings and Neighborhood Income in Chicago

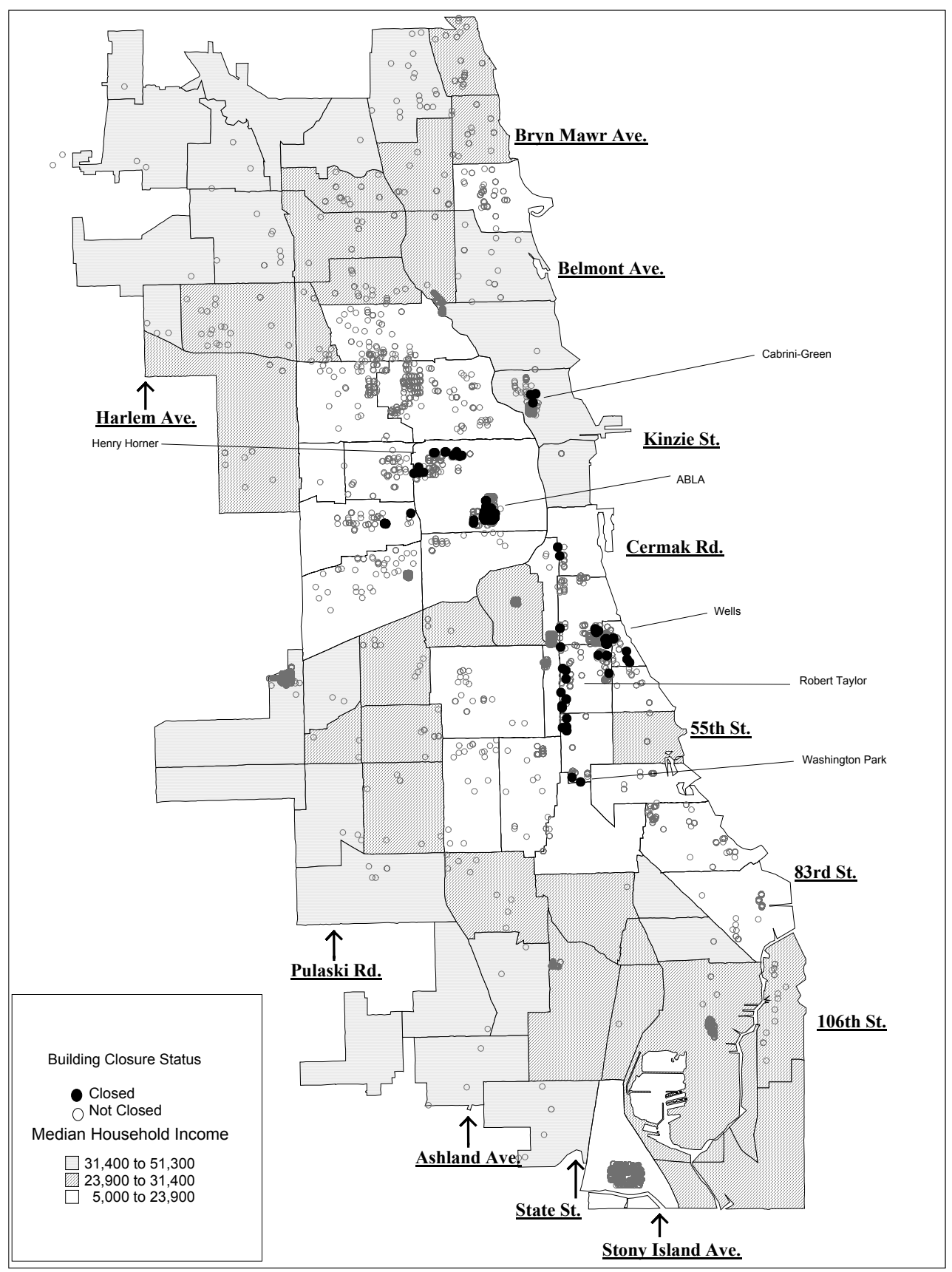




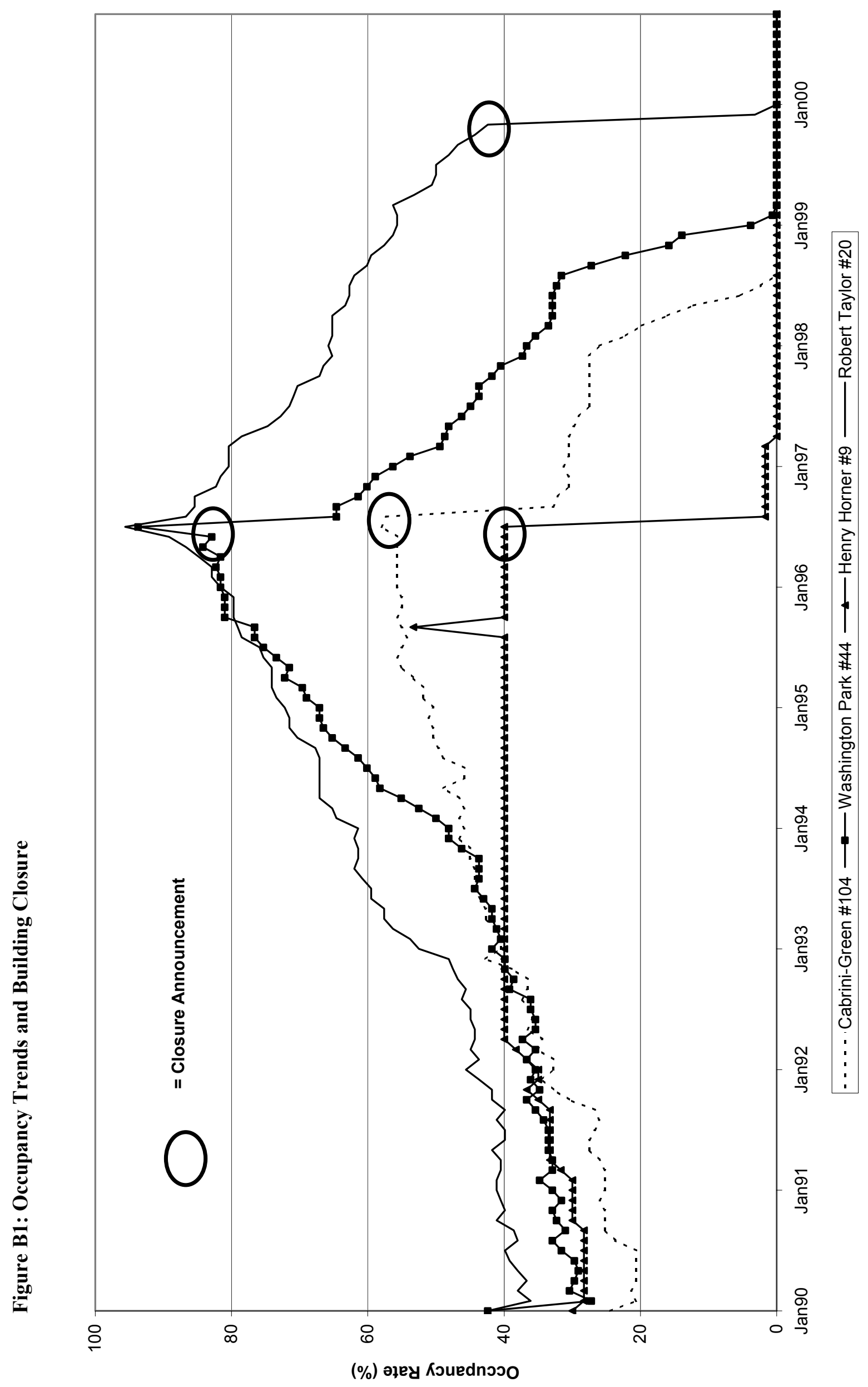

